\title{
Disegnare il mutevole. II concorso per il grattacielo Peugeot di Maurizio Sacripanti
}

\author{
Francesco Maggio \\ Chiara La Rosa
}

Abstract

Maurizio Sacripanti, una delle figure più significative dell'architettura italiana della seconda metà del ventesimo secolo, ha sperimentato il proprio linguaggio architettonico awalendosi delle influenze della letteratura e dell'arte contemporanea. Nell'architetto romano convivono, infatti, diverse esperienze artistiche, l'arte programmata, la megastruttura e lo strutturalismo, l'optical-art, l'architettura visionaria e l'arte cinetica, queste forse quelle più interessanti; altri riferimenti sono rintracciabili nelle esperienze precedenti di De Stijl e del Futurismo. II progetto per il concorso del grattacielo Peugeot a Buenos Aires sembra contenere, nella sua ideazione e nei disegni di progetto, continui rimandi a tutte le correnti artistiche contemporanee che Sacripanti indagava con attenzione critica e con l'intelligenza delle possibili trasposizioni nel suo fare architettonico.

In questo senso Sacripanti definisce nel grattacielo Peugeot una maglia, owero una regola entro cui si sviluppa il corpo dell'edificio modificabile nel tempo (architettura programmata/visionaria), crea una struttura dal gusto quasi metabolista, gestisce modificabilità e trasformazione in maniera esemplare nella mutevolezza dei prospetti giungendo a sperimentazioni dell'optical-art. Le inedite rappresentazioni di progetto che accompagnano il testo, vere e proprie operazioni di analisi grafica, vogliono essere strumento di verifica del pensiero dell'architetto romano.

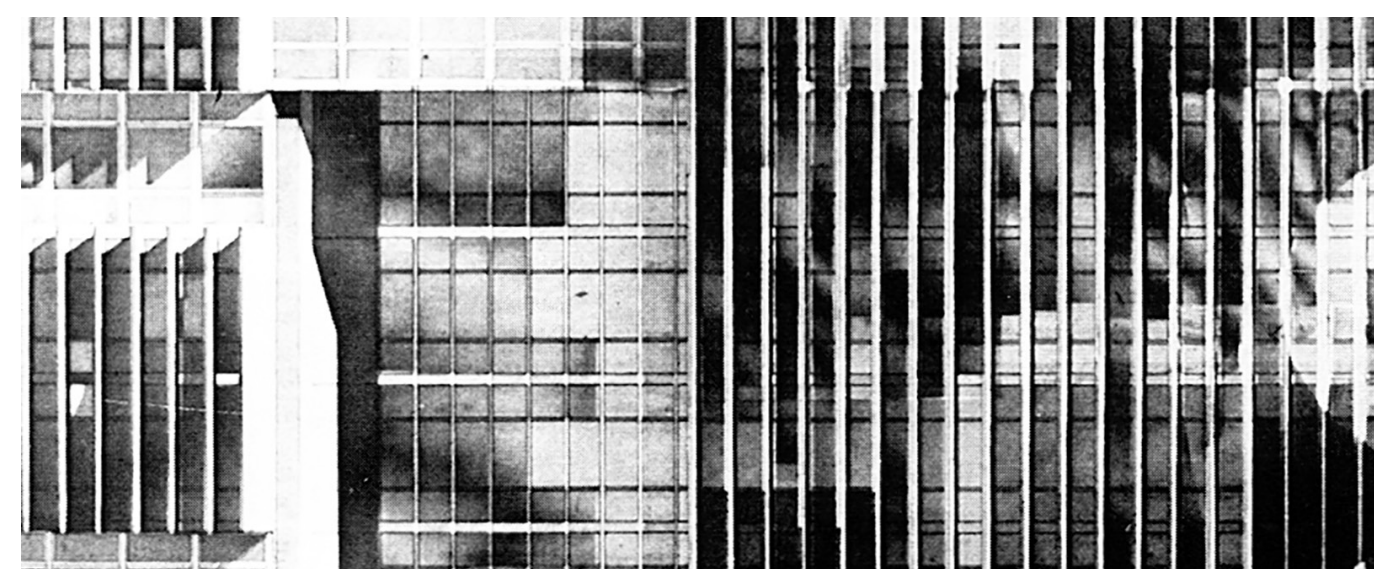




\section{Introduzione}

II concorso è uno strumento straordinario per sostenere l'architettura di qualità attraverso proposte differenti dal cui confronto scaturiscono dibattiti valutazioni critiche. Molte di queste, come nel caso del concorso Peugeot, pur rimanendo sulla carta, costituiscono, attraverso i disegni, autentiche testimonianze del clima culturale del periodo in cui sono stati prodotti.

I disegni di Maurizio Sacripanti per il grattacielo Peugeot a Buenos Aires indicano come l'autore esplori temi a lui cari, come per esempio il concetto di 'mutevole', attraverso sia rappresentazioni grafiche che attraverso il plastico. Un particolare del prospetto mostra in maniera eloquente i caratteri di mutevolezza di uno dei fronti del grattacielo (fig. I); lo stesso Sacripanti, nel descrivere il suo modo di disegnare afferma che "più che disegnare a riga e squadra, disegno nello spazio. Dell'architettura, poi, ne va disegnato solo un pezzetto" [Ciancarelli, Remiddi 1998, p. 196]. L'affermazione dell'architetto romano trova riscontro in molti suoi progetti, primi fra i quali quello per il padiglione a Osaka, per il Museo della Scienza a Roma e per il Museo degli Eremitani a Padova.

Sacripanti percepisce in toto il programma previsto dal concorso in cui le società 'abitanti' il grattacielo dovevano avere massima visibilità all'esterno configurandosi, allo stesso tempo, come entità autonome, ma amplifica il carattere di mutevolezza attraverso brise soleil e volumi aggettanti che creano un particolare gioco di luci e ombre.

Vedute notturne del progetto sacripantiano (fig. 2) ricordano il pensiero di Le Corbusier su Buenos Aires in cui il maestro svizzero immagina i grattacieli della nuova città: li immagina di notte, brillanti e riflessi nelle acque della baia e annota questa vivida immagine su un piccolo foglietto di carta (fig. 3).

Incaricato nel 1938 dal governo argentino di un vero e proprio piano regolatore della capitale, quel foglietto si trasforma negli elaborati grafici perfetti e complessi del piano conservando inalterata quell'immagine grandiosa, avuta una notte di dieci anni prima.

II progetto di Le Corbusier non fu mai realizzato; tuttavia la sua influenza e le sue idee hanno rafforzato l'ispirazione della costruzione del grattacielo Peugeot.

Fig. I. M. Sacripanti, pardel grattacielo Peugeot.

Fig. 2. M. Sacripanti, foto del plastico del grattacieo Peugeot.
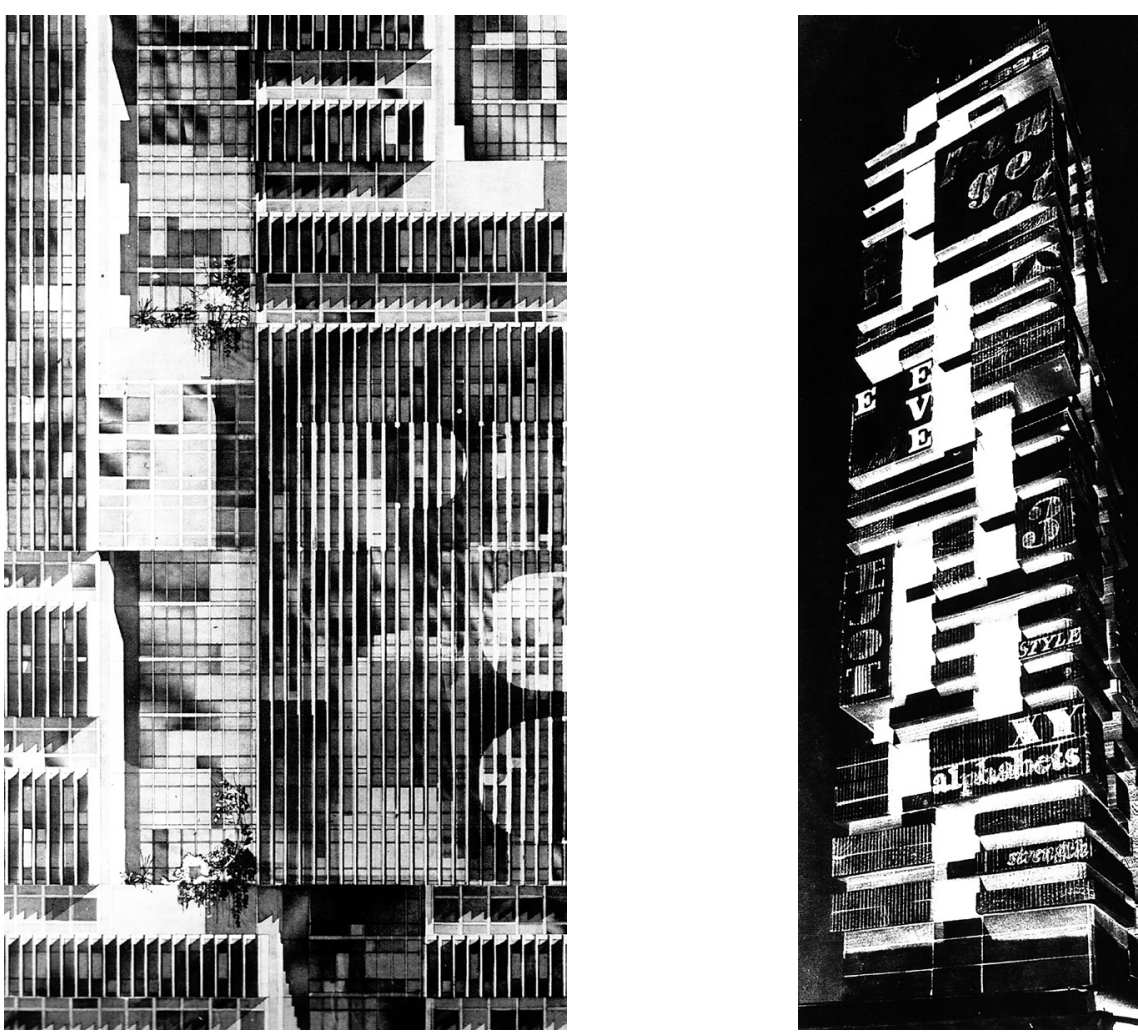


\section{Concorso Internazionale Peugeot}

Questo concorso è stato una delle occasioni più importanti per Buenos Aires, non solo perché avrebbe comportato la realizzazione dell'edificio più alto del Sud America, ma soprattutto per le reazioni, le risposte e il dibattito che esso ha generato.

Il concorso ricevette ben 228 proposte di progetti provenienti da quasi una trentina di paesi. La Foreign Building Investment Company S.A., la società di capitali costituita dalla casa automobilistica Peugeot, promotrice del concorso, dispose per i premiati un elevato compenso economico.

La Peugeot fu un riferimento per l'architettura del tempo, perché propose un tema significativo proprio nel momento in cui i grattacieli erano intesi come l'esempio paradigmatico dell'architettura moderna.

II grattacielo sarebbe dovuto essere costruito in un punto nevralgico della capitale argentina: venne infatti pensato in prossimità di Plaza San Martín, terminale di arterie commerciali e zona prestigiosa di grandi residenze, posizionato vicino alla rete infrastrutturale con immediato accesso alle stazioni ferroviarie del Retiro e alla rete di metropolitane; la vicinanza allo sbocco della Avenida 9 de Julio, di futura realizzazione, inoltre avrebbe garantito una connessione diretta con il cuore urbano della città (fig. 4).

The Foreign Building and Investment Company propose il programma: un edificio, destinato alla Società Peugeot, che coprisse circa 140.000 metri quadrati, comprendente un centro commerciale e culturale per un investimento totale di 20.000 .000 di dollari. Si sarebbe dovuto proporre un grattacielo alto almeno 60 piani che avesse potuto incentivare i partecipanti a ideare un elemento architettonico emergente. L'intenzione degli investitori non sarebbe stata solo quella di realizzare un edificio monumentale, ma di proporre un vero e proprio esempio di architettura contemporanea.

II programma dell'edificio Peugeot era ampio e complesso e richiedeva un gruppo di uffici, un insieme di alloggi, uno spazio commerciale con 40 locali di una superficie media di $20 \mathrm{mq}$ per formare una galleria commerciale e altri 10 locali di $60 \mathrm{mq}$ per filiali bancarie, spazi per ospitare spettacoli teatrali, balletti, concerti, conferenze, congressi nazionali e internazionali, cinema, ecc., due anfiteatri da 500 e da 250 posti, una sala per ricevimenti, tre ristoranti, gli spazi del garage per un totale di 30.000 mq, gli spazi per i servizi generali ed ancora un'infermeria e strutture mediche.

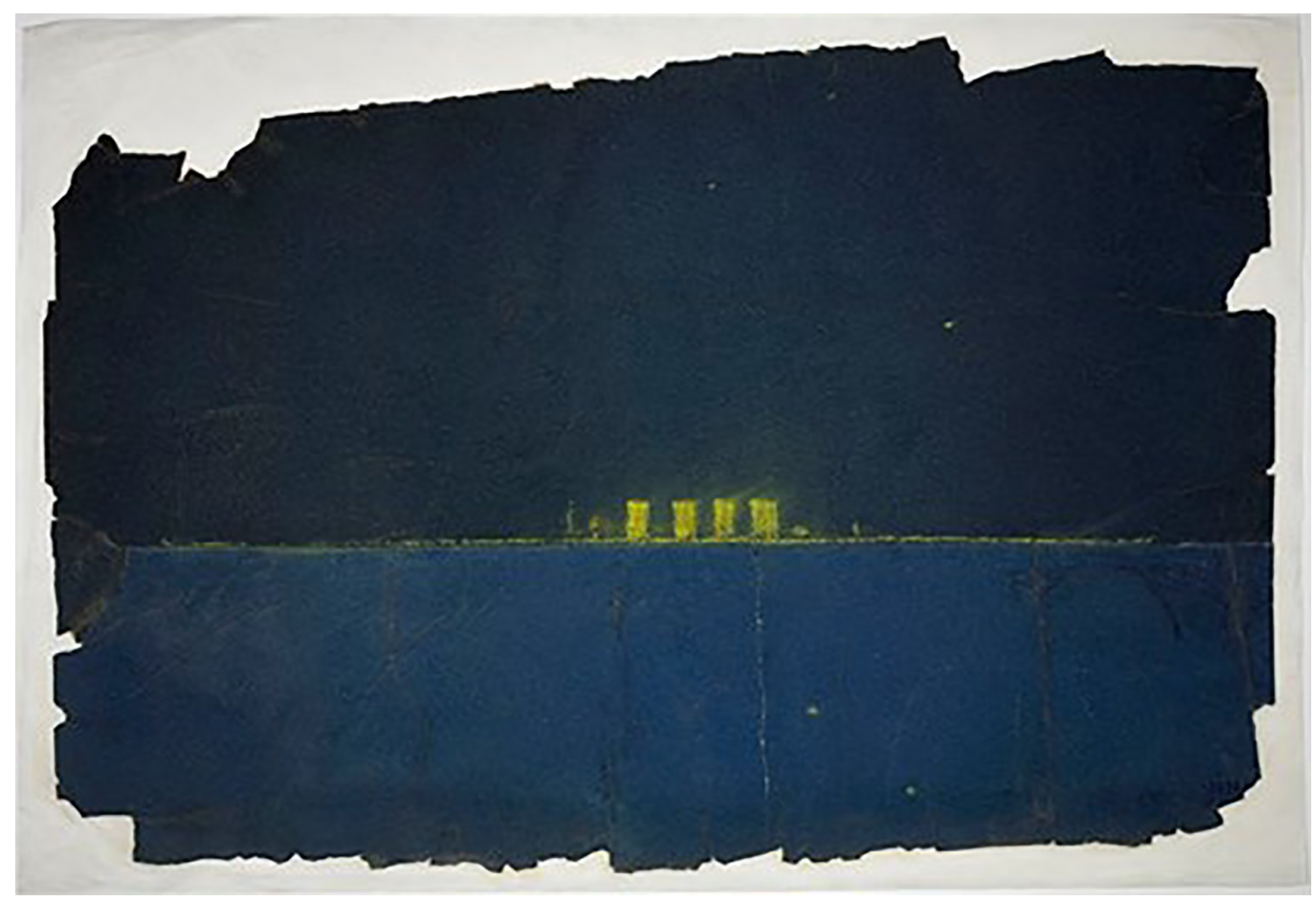


Per quanto riguardava la dimensione e l'altezza della torre, il programma fece riferimento al Regolamento di costruzione per la città di Buenos Aires.

La giuria formata da Martin Noel (Presidente), da Francisco Garcìa Vàzquez, e Francisco Rossi (Segretari) e da Eugenio Beadouin, Aberto Prebisch, Affonso Eduardo Reidy, Marcel Breuer e Federico Adolfo Ugarte, lavorò in modo serrato dal 7 al 26 marzo 1962, giorno in cui vennero emessi i risultati ufficiali.

I criteri per la scelta dei progetti vincitori riguardarono l'approccio generale e la relazione con il paesaggio urbano, i valori architettonici, gli aspetti funzionali, gli aspetti tecnici, le soluzioni parziali e il rispetto delle regole del concorso (fig. 5).

II primo premio venne assegnato al gruppo composto dagli architetti brasiliani Roberto Claudio Aflalo, Plinio Croce, Giancarlo Gasperini e dall'architetto argentino Eduardo Patricio mentre a Maurizio Sacripanti venne assegnata una menzione d'onore così motivata: "Questo progetto preliminare si distingue per la ricerca estetica dell'autore, che si basa su una sapiente applicazione di lastre di alluminio, che cercano di difendere l'interno dall'azione dei raggi solari, e allo stesso tempo ottiene un trattamento esterno di eccezione. Queste lamelle vengono proposte auto-regolabili, attraverso l'azione di un sistema di fotocellule elettronico. La presentazione delle facciate è un'eccezione e mostra la sensibilità dell'autore e la possibilità di esprimersi in un prezioso linguaggio plastico. È necessario sottolineare che c'è un'assenza totale di armonia tra lo studio delle piante, la struttura e le funzioni rispetto
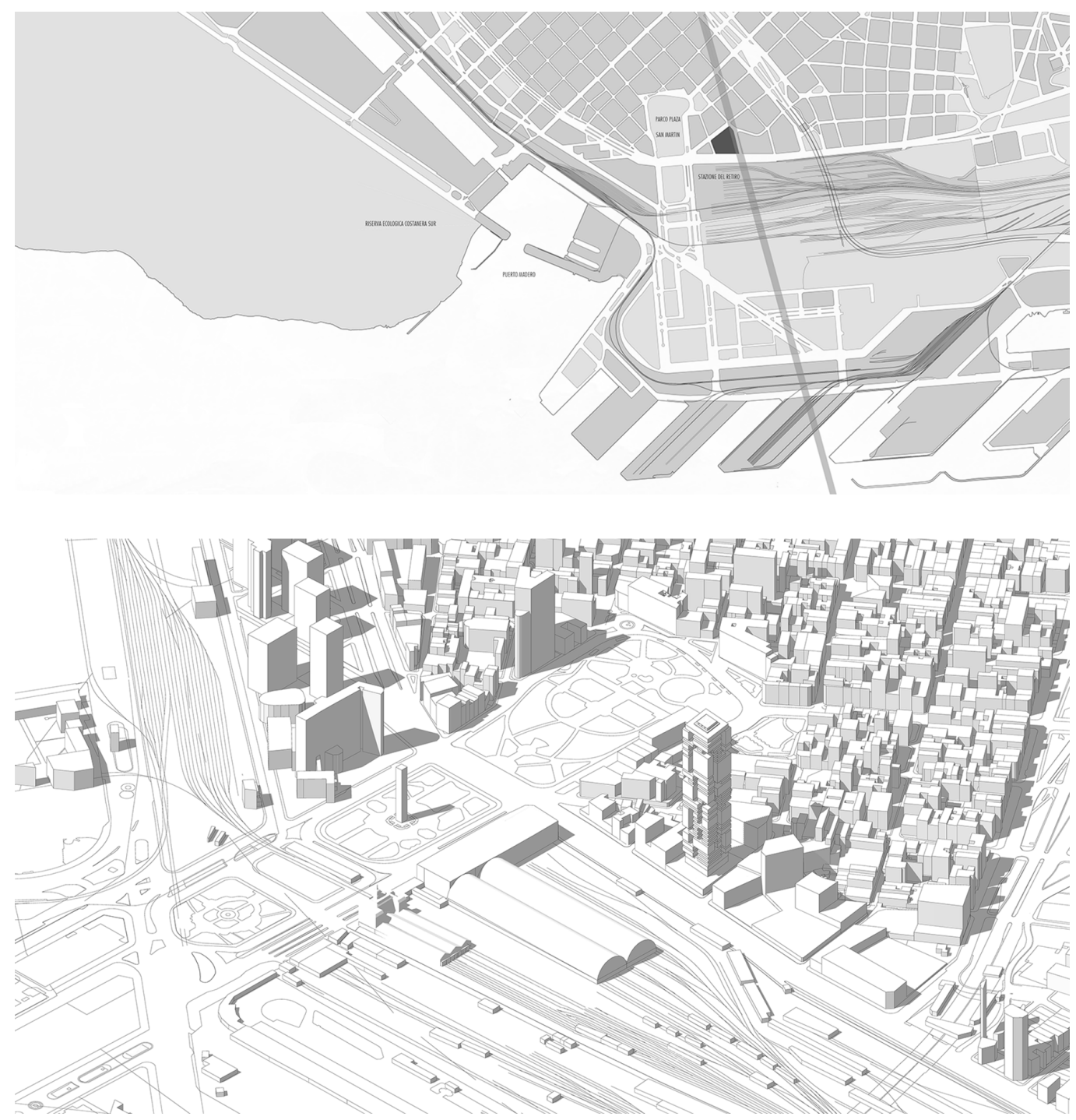
alla qualità dimostrata nel trattamento delle facciate. È considerato critico governare l'intera composizione su un sistema non ortogonale (inclinazione corrispondente a 75 a 55 gradi come indicato nella relazione) solo per accompagnare entrambe le linee municipali. La soluzione errata delle diverse funzioni produce ad un eccesso di superfici utilizzabili, motivo per cui questo studio supera oltre i 40.000 metri quadrati fissati dal bando" [I].

In patria, invece, il progetto di Sacripanti venne molto apprezzato.

Bruno Zevi, in L'architettura. Cronache e Storia scrisse: "La giuria assegnando a Sacripanti una semplice menzione d'onore ha, a nostro avviso, mancato l'occasione di segnalare adeguatamente una soluzione assai brillante in tutto, rispondendo allo spirito del concorso. II confronto con gli altri progetti premiati si impone: non quello vincitore, né gli altri appaiono superiori a quello che presentiamo né per coerenza, né per fantasia" [Zevi I963, p. I 65].
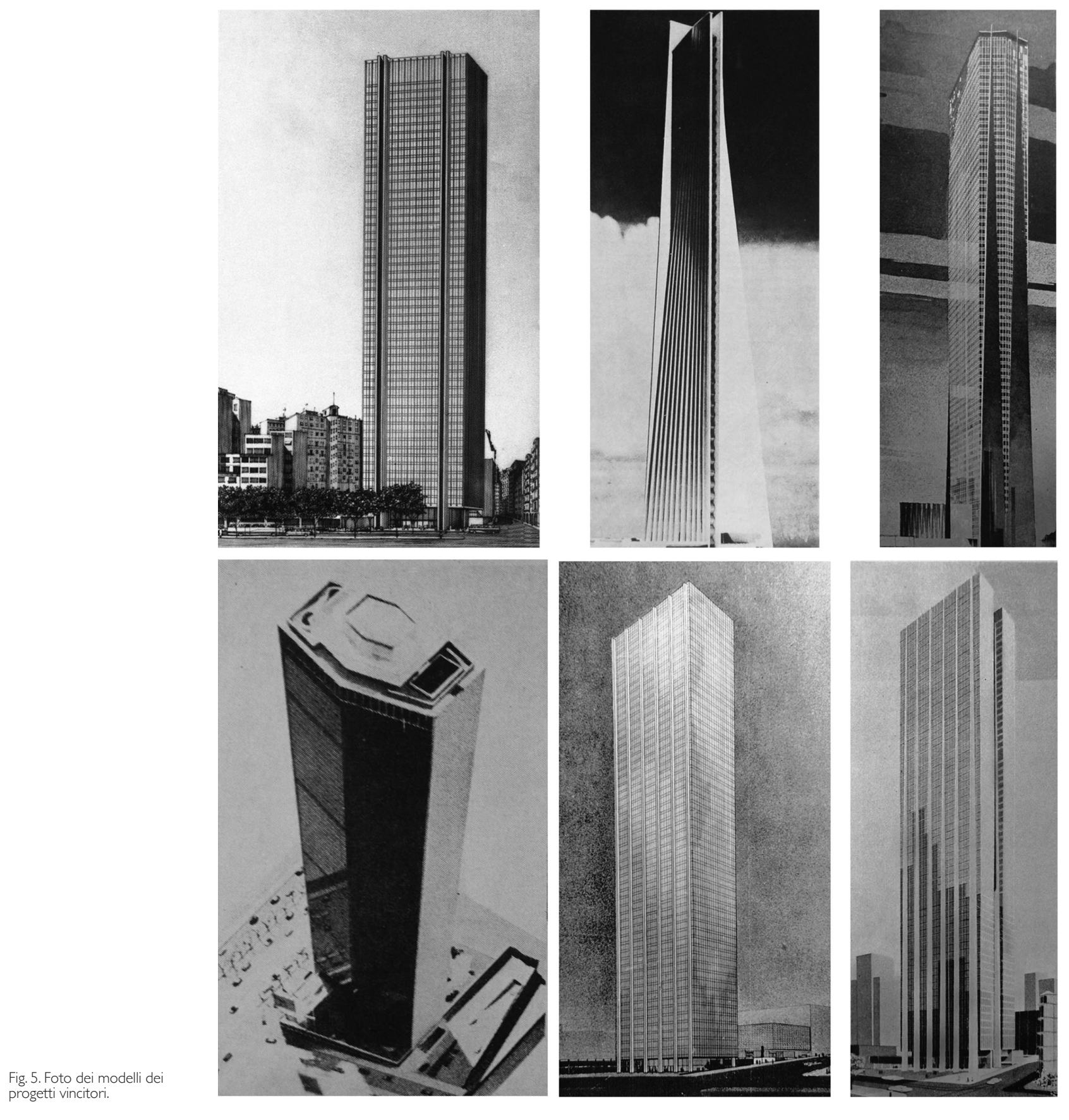


\section{II progetto di Sacripanti}

II progetto proposto da Sacripanti, probabilmente inteso provocatorio, non venne capito nella sua reale portata: è un edificio mutevole, che si sottrae ad un'immagine fissa, rivestito di lamine sulle quali si può scrivere e che, attraverso il loro movimento, può divenire un enorme cartellone pubblicitario (figg. 6, 7).

II termine mutevole è un concetto intenso e profondo che sposa totalmente la poetica di Sacripanti e che trova le sue radici nella filosofia, a cominciare dal panta rei di Eraclito, ovvero il vedere il mondo come un cambiamento continuo.

La definizione stessa di mutevole ci conduce ad un significato più complesso: si parla di mutevolezza in merito a qualcosa che cambia spesso, che è incostante e volubile: lo usiamo spesso quando parliamo del tempo ma anche dell'umore. La mutevolezza è dunque una condizione esistenziale dell'essere umano; e questo Sacripanti lo aveva capito bene, contemplando la natura del nostro mondo e il suo unico elemento duraturo, la mutevolezza, appunto.

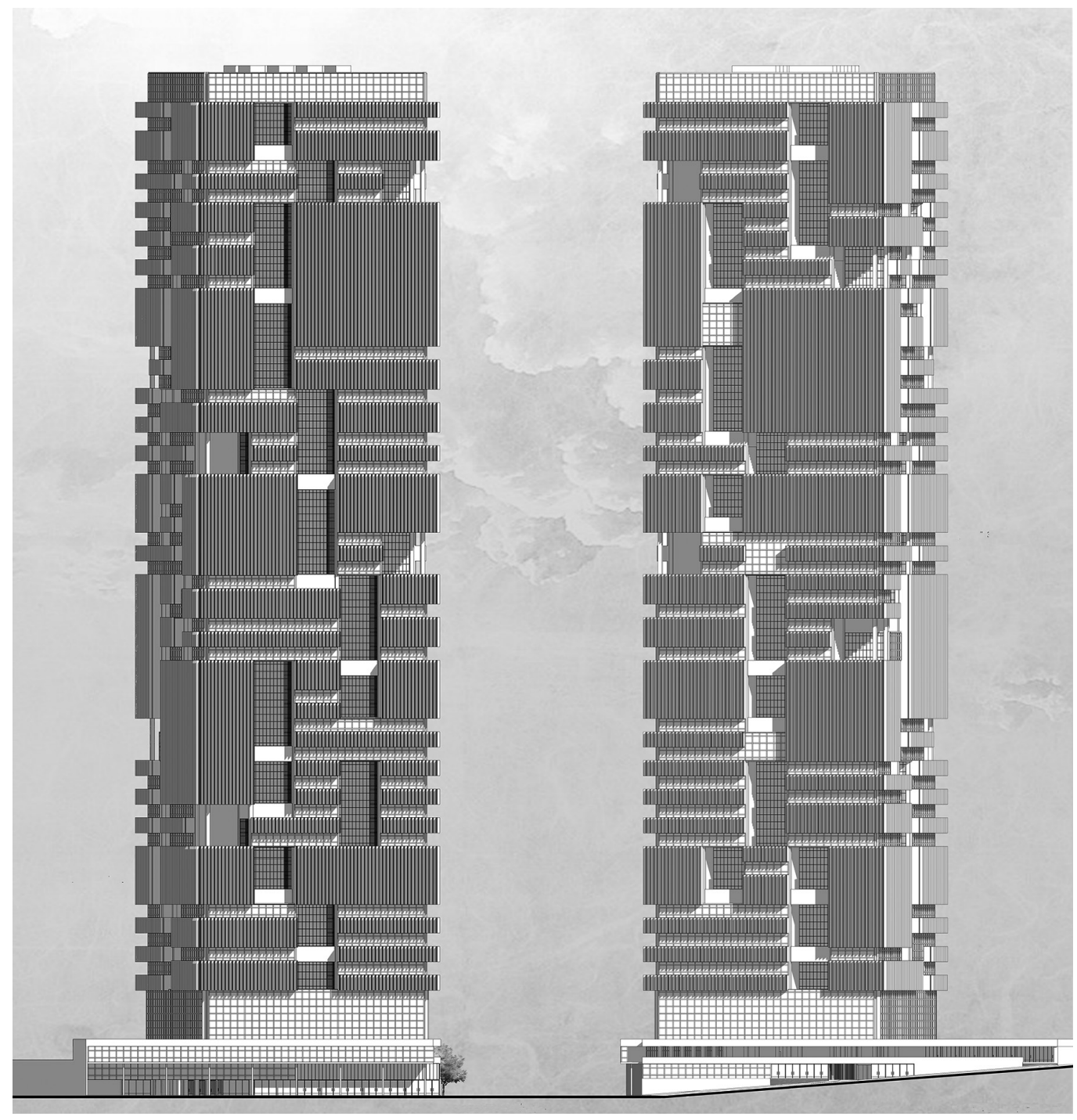


II grattacielo fu pensato con una struttura fortemente articolata, costituita da blocchi sovrapposti, sospesi, aggettanti, contrapposti ai vuoti delle logge e dei giardini che scandivano la composizione delle facciate; una nuova concezione dell'edificio a torre ottenuto per scomposizione di volumi e pensato per le necessità spaziali e funzionali di ciascuna azienda che si sarebbe insediata (fig. 8).

Ecco le premesse che condussero all'elaborazione dell'idea progettuale: conseguire la massima lettura delle aziende all'esterno del grattacielo non solo attraverso la pubblicità, ma soprattutto attraverso i volumi, variabili, che rappresentavano ciascuna impresa. Da un lato vi fu la volontà di creare un manufatto architettonico parzialmente modificabile che rispondesse nel tempo alle esigenze degli utenti e dei fruitori, dall'altra utilizzare la pubblicità come elemento compositivo.

Fig. 7. II progetto di Sacripanti, sezione
(elaborazione grafica di Chiara La Rosa).

Fig. 8. II progetto di Sacripanti, esploso assonometrico (elaborazione grafica di Chiara La Rosa).
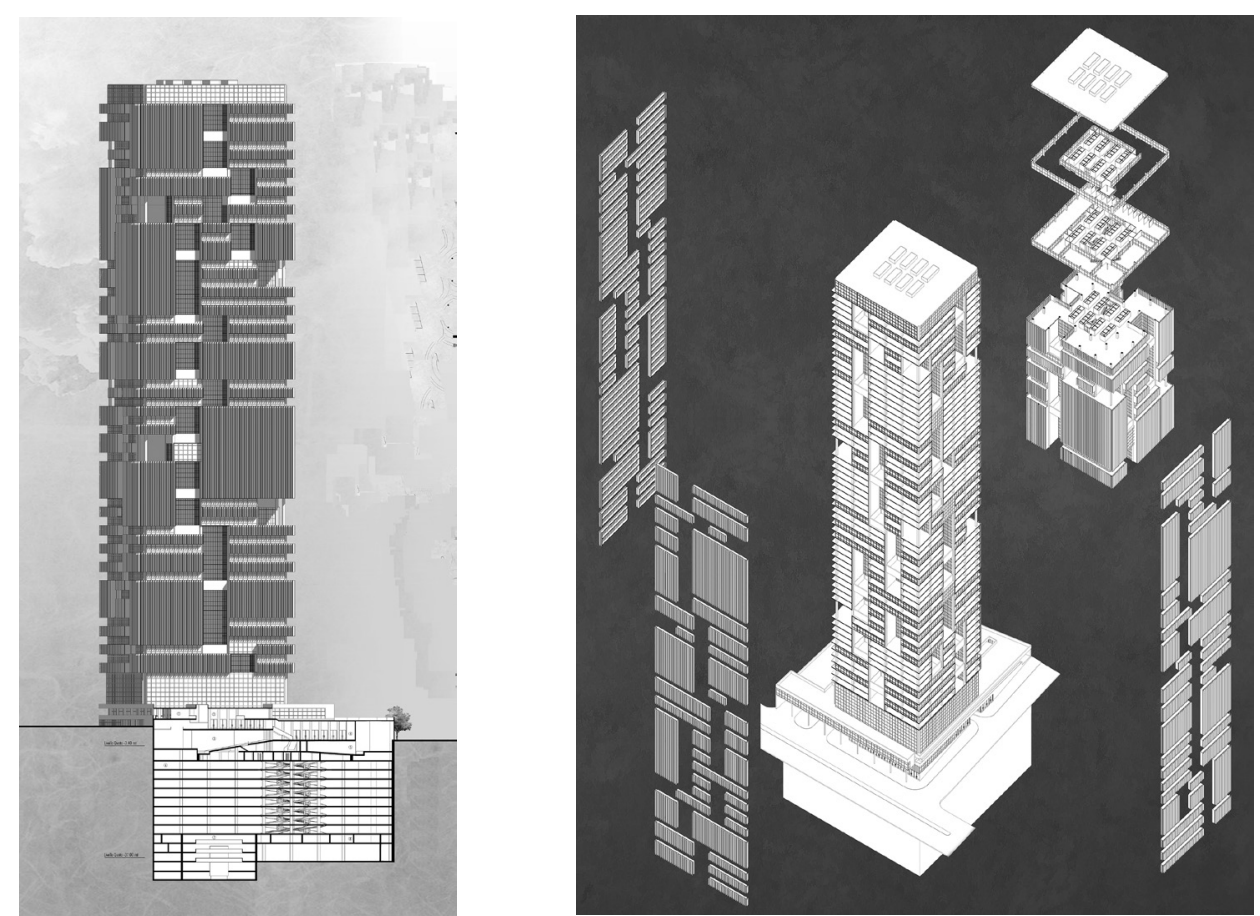

In questo progetto è fondamentale il passaggio dall'estetica delle cose al processo generativo delle cose stesse; questo concetto, che poi è rimasto in qualche modo presente nella poetica di Sacripanti, riguarda il non progettare degli spazi conclusi, ma delle alternative all'interno delle quali si possono trovare diverse soluzioni spaziali (fig. 9). II fusto del grattacielo, interamente modulato, segue una maglia di base di 8,40 $\mathrm{m} \times 8,40 \mathrm{~m}$ per un totale di $42 \times 42 \mathrm{~m}$, con angoli di $75^{\circ}$ e $105^{\circ}$.

Gli angoli vengono definiti dall'inclinazione della morfologia dell'isolato in cui sarebbe dovuto sorgere, ossia dall'angolo che si crea dall'incontro tra l'Avenida Libertador e la Calle Esmeralda, e che diventa l'elemento compositivo principale nella definizione della maglia di base che controlla, con tutte le proprie combinazioni, un edificio la cui variabilità è ricchissima (fig. 10).

La pianta si sviluppa su tre anelli concentrici che rappresentano tre superfici funzionalmente e costruttivamente autonome: la superficie interna contiene i collegamenti verticali, la superficie intermedia i servizi, gli ingressi, i bagni e i guardaroba, quella esterna gli spazi degli uffici (fig. I I). 
Fig. 9. II progetto di Sacripanti, prospettive degli interni, (render di Chiara La Rosa).
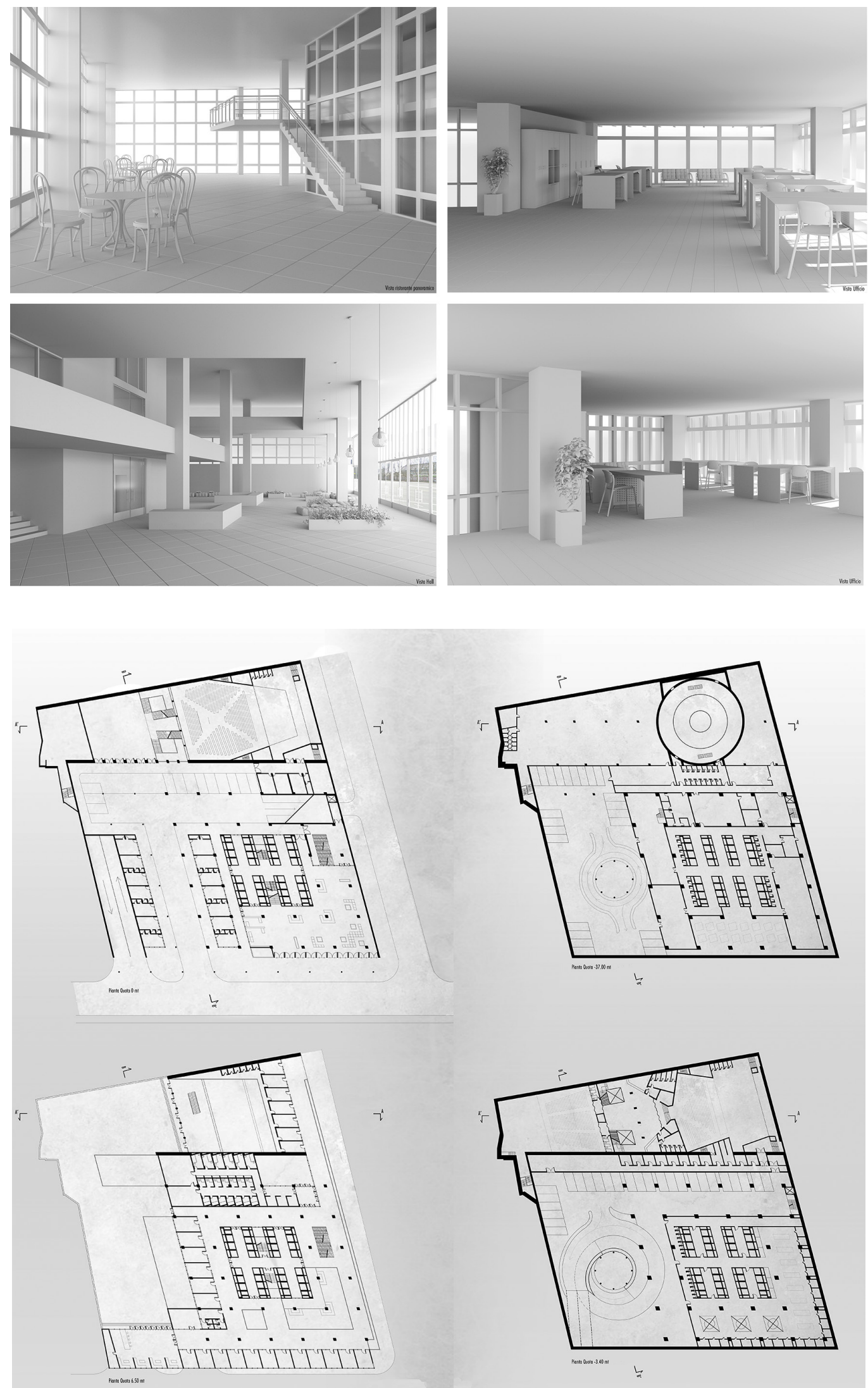
Le forme proposte erano pensate con e senza sbalzo. Le prime potevano sia saldarsi sul piano orizzontale sia sommarsi su quello verticale e all'esterno individuavano i volumi degli uffici progettati in aggetto. II grattacielo si costituiva così come somma dei volumi corrispondenti alle aziende che lo avrebbero occupato, scandito da grandi tagli che avrebbero consentito la visione dall'esterno del cuore del grattacielo. Sul grattacielo, a copertura delle superfici aggettanti e a difesa del sole, erano previste lamelle di alluminio auto-orientabili attraverso un sistema di fotocellule elettroniche. Le lamelle avrebbero portato nel loro spessore segmenti di metallo policromo e di canali luminosi che avrebbero formato lettere e figure a indicare i nomi delle aziende.

Sacripanti da una forma definitiva al suo grattacielo, nonostante avesse previsto che le facciate, sarebbero mutate con il tempo a seconda delle esigenze delle aziende che avrebbero occupato gli spazi (fig. 12).

Lo sfruttamento figurativo della pubblicità è elemento intrinseco, fattore di forma del grattacielo; ad essa Sacripanti, lancia una sfida e decide di sfruttarla a servizio dell'architettura in cui l'elemento commerciale e pubblicitario, la politica dei consumi, l'insicurezza, la variabilità sono strumenti al servizio della progettazione.

In questo modo, alle singole attività che si insediano nel grattacielo, è concessa la possibilità di darsi riconoscibilità. L'architettura diventa allora specchio della società, oggetto di consumo e per il consumo, acquisendo una valenza concettuale legata alle ricerche artistiche contemporanee.

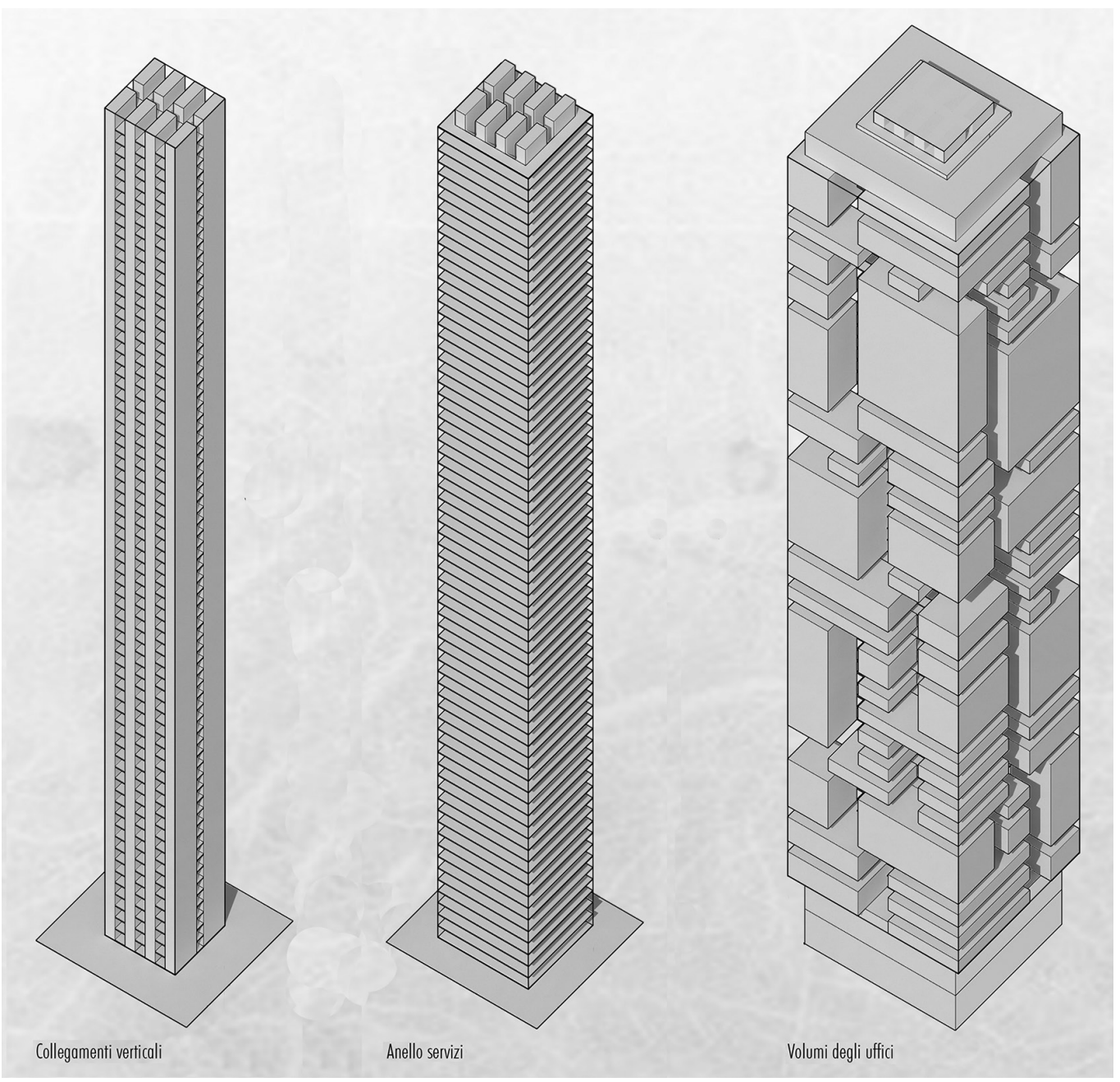


II grattacielo dunque incarna un'idea di perenne variabilità dell'edificio che riflette la mutevolezza dell'uomo e delle attività che svolge e organizza. II mutevole diventa una componente essenziale: si utilizzano strumenti mobili, consumabili, alterabili per definizione. La costruzione è interamente modulata, possibile quindi di totale prefabbricazione.

Il tempo entra nel progetto per un mondo come il nostro, consumato nel tempo.

Per questo individuò nel disegno, non tanto un sostituto della realizzazione, quanto un ambito parallelo nel quale le sue proposte vivessero una condizione di concretezza.

\section{Conclusioni}

L'analisi grafica e il ridisegno di architetture mai costruite non si configurano mai come azioni autonome perché se si assume "la centralità del progetto quale forma specifica della conoscenza architettonica, la rappresentazione si configura come luogo privilegiato tanto della sua formazione ed elaborazione, quanto dell'interpretazione e dell'analisi critica dell'opera edificata" [Ugo 2004, p 7]. Se si considera il disegno come uno dei modi delle forme di conoscenza, la differenza tra opera edificata e non realizzata è facilmente superabile; ciò perché il progetto, nelle intenzioni del suo autore, è sempre 'costruibile' anche quando, al limite, indaga i campi dell'utopia; perché costruire è un pensare [Heidegger 1952].
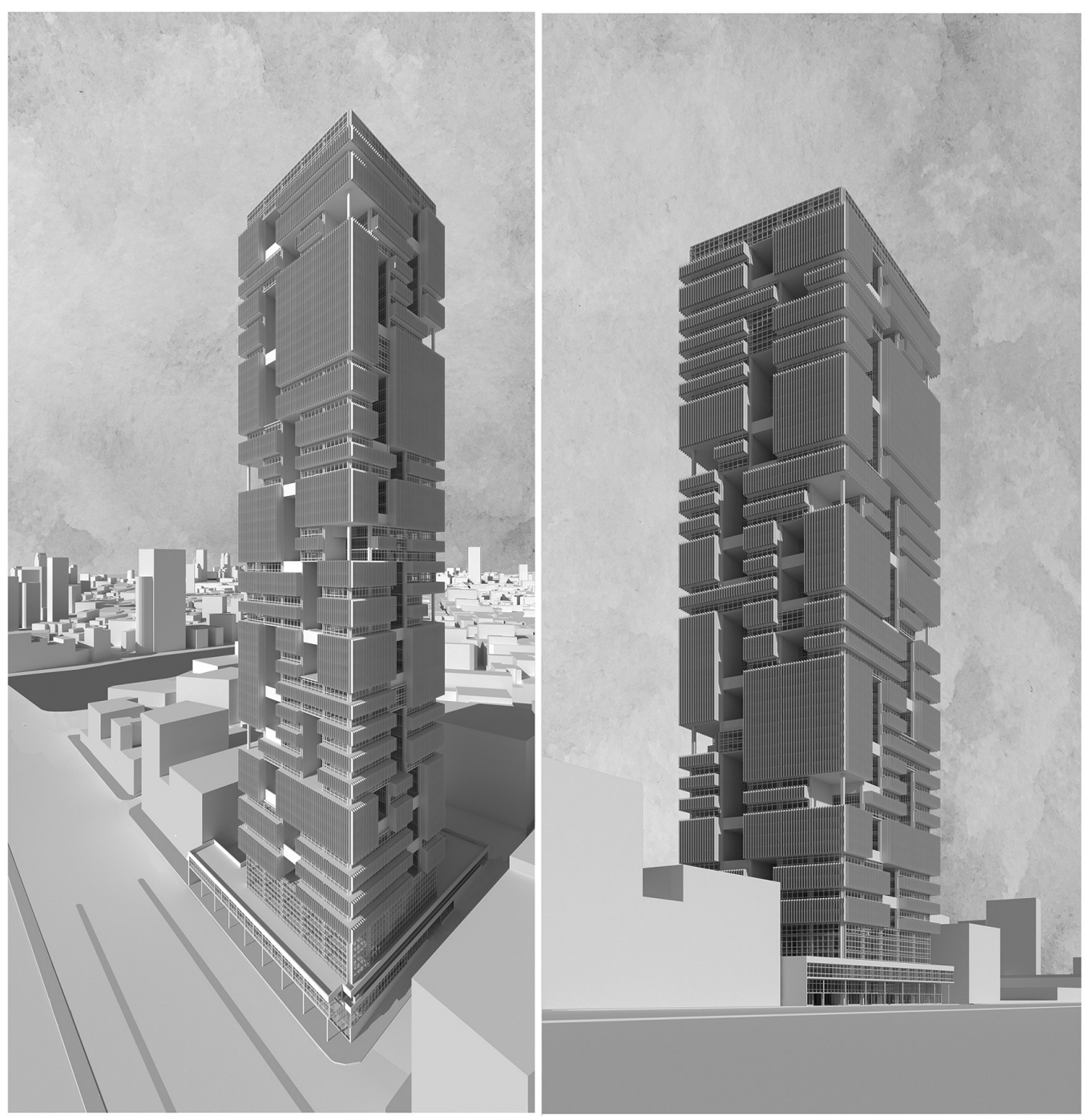
L'architettura può essere raccontata con testi e con nuove e inedite rappresentazioni percorrendo i luoghi della feconda interazione tra produzione teorica ed elaborazione digitale. In tal senso il disegno digitale, per la sua straordinaria 'elasticità', è molto utile per l'analisi grafica di quei progetti di 'architetture nel cassetto' che, per il loro essere pura espressione di un'idea 'incontaminata', possiedono una espressività maggiore dei progetti realizzati.

"I modelli digitali d'architettura che sono apparsi fino a oggi hanno apportato un cambiamento che potremmo definire qualcosa di simile alla 'rivoluzione tipografica' introdotta quando Sebastiano Serlio e Palladio pensarono di comunicare l'architettura attraverso le pagine stampate di un libro. L'aspetto cruciale di tale rivoluzione non consiste tanto nella costruzione d'illusioni tridimensionali più efficaci che nel passato, quanto nella trasformazione della rappresentazione tridimensionale di un edificio da immagine a sistema conoscitivo, vale a dire in una banca dati d'informazioni spaziali, dimensionali e relazionali ben precise. La lettura di un'opera [...] introduce la necessità di nuove notazioni: non solo una verifica sperimentale d'importanti connotazioni spaziali, o di elementi come la qualità e la quantità della luce, ma anche la verifica percettiva dello spazio come sarà realizzato" [Gaiani 20। I, p. I2] [2].

\section{Note}

[I] Concurso del Edificio Peugeot, 1962, p. 33.

[2] Pur condividendo le posizioni espresse nell'articolo, risultato di elaborazioni comuni, il paragrafo II Concorso Internazionale Peugeot è da attribuire a Francesco Maggio insieme all'Introduzione e alle Conclusioni, mentre il paragrafo II progetto di Sacripanti è da attribuire a Chiara La Rosa.

\section{Riferimenti bibliografici}

Albisinni Piero, De Carlo Laura (a cura di). (20I I). Architettura/Disegno /Modello, verso un archivio digitale dell'Opera di Maestri del XX secolo. Roma: Gangemi Editore.

Ciancarelli Luca, Remiddi Gaia (1998). Più di questo non so dirvi... Intervista a Maurizio Sacripanti. In Neri Maria Luisa, Thermes Laura (a cura di). Maurizio Sacripanti maestro di architettura, 19 I6-1996. Roma: Gangemi, pp. 191-200

Concurso del Edificio Peugeot, Esmeralda y Libertador.Trabajos premiados. In Nuestra Arquitectura, 39I, I 962, Buenos Aires. p. 33.

Gaiani Marco (20 I I). Presentazione. In Maggio Francesco. Eileen Gray. Interpretazioni grafiche. Milano: Franco Angeli

Garimberti Marta, Susani Giuseppe (1967). Sacripanti. Architettura.Venezia: Cluva.

Giancotti Alfonso (2000). Maurizio Sacripanti: altrove. Torino:Testo\&lmmagine.

Heidegger Martin (1952). Costruire abitare pensare. In Vattimo Gianni (a cura di) (20I4). Saggi e discorsi. Milano: Mursia.

Neri Maria Luisa, Thermes Laura (a cura di). (1998). Maurizio Sacripanti maestro di architettura, 1916-1996. Roma: Gangemi Editore.

Sacripanti Maurizio (1973). Città di frontiera = Frontier City. Roma: Bulzoni Editore.

Ugo Vittorio (1994). Fondamenti della rappresentazione architettonica. Bologna: Ed. Esculapio.

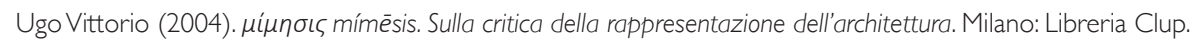

Zevi Bruno (1963). II grattacielo Peugeot. In L'Architettura. Cronache e Storia, anno VIII, 87, p. I 654.

\section{Autori}

Francesco Maggio, Università di Palermo, francesco.maggio@unipa.it

Chiara La Rosa, Università di Palermo, larosachiaa@gmail.com

Per citare questo articolo: Maggio Francesco, La Rosa Chiara (2020). Disegnare il mutevole. Il concorso per il grattacielo Peugeot di Maurizio Sacripanti. In Arena A., Arena M., Brandolino R. G., Colistra D., Ginex G., Mediati D., Nucifora S., Raffa P. (a cura di). Connettere. Un disegno per annodare e tessere. Atti del $42^{\circ}$ Convegno Internazionale dei Docenti delle Discipline della Rappresentazione/ Connecting. Drawing for weaving relationships. Proceedings of the 42th International Conference of Representation Disciplines Teachers. Milano: FrancoAngeli, pp. 2383-2404. 


\title{
Drawing the Changeable. The Competition for the Peugeot Skyscraper of Maurizio Sacripanti
}

\author{
Francesco Maggio \\ Chiara La Rosa
}

Abstract

Maurizio Sacripanti, one of the most significant figures in Italian architecture in the second half of the twentieth century, has experimented with his own architectural language making use of the influences of literature and contemporary art. In the Roman architect, in fact, different artistic experiences coexist, programmed art, megastructure and structuralism, optical-art, visionary architecture and kinetic art, these perhaps the most interesting ones. Other references can be found in the previous experiences of De Stijl and Futurism. The project for the competition for the Peugeot skyscraper in Buenos Aires seems to contain, in his conception and drawings, continuous references to all the contemporary artistic currents that Sacripanti investigated with critical attention and with the intelligence of the possible transpositions in his architectural 'making'.

In this sense Sacripanti defines the Peugeot skyscraper as a knits, or rather a rule within which the body of the building can be modified over time (programmed/visionary architecture), creates a structure with an almost metabolist taste, manages modifiability and transformation in an exemplary way in the mutability of the elevations, arriving at experimentations of optical-art. The unpublished project representations that accompany the text, real operations of graphic analysis, are intended to be an instrument of verification of the Roman architect's thought.

Keywords

past, memory, visions, competition, redrawing.

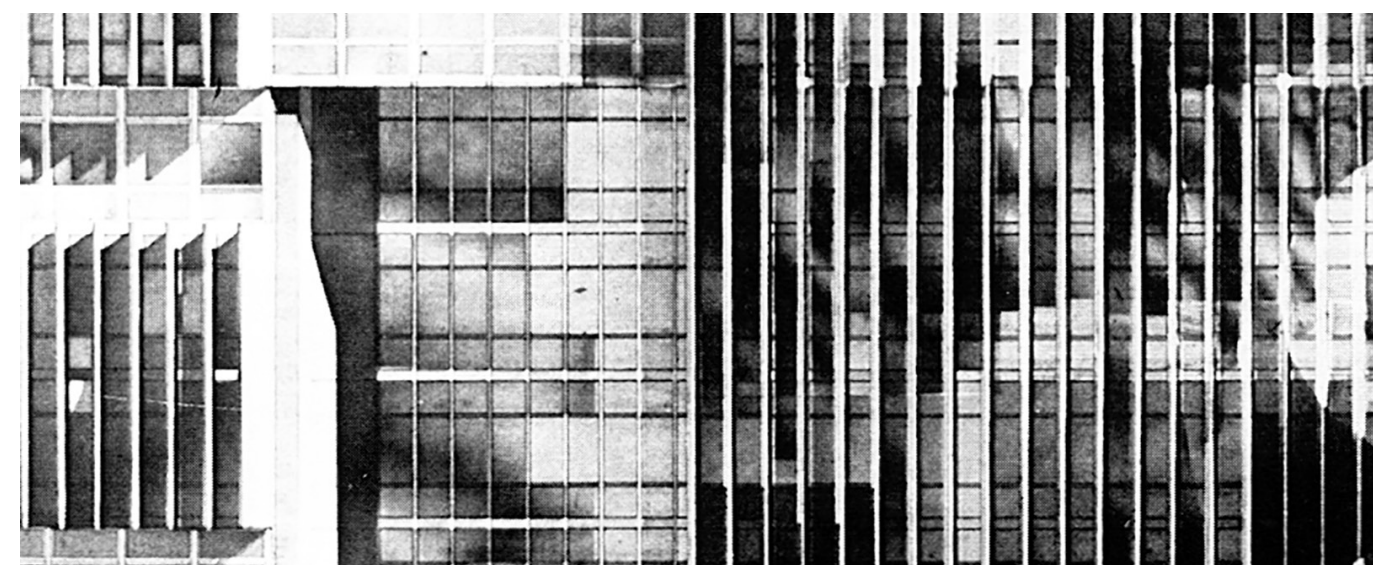




\section{Introduction}

The competition is an extraordinary tool to support quality architecture through different proposals from which critical evaluations are debated. Many of these, as in the case of the Peugeot competition, while remaining on paper, are, through drawings, authentic evidence of the cultural climate of the period in which they were produced.

Maurizio Sacripanti's drawings for the Peugeot skyscraper in Buenos Aires indicate how the author explores themes dear to him, such as the concept of 'mutabl'e, through both graphic representations and plastic. A detail of the elevation eloquently shows the characters of mutability of one of the façades of the skyscraper (fig. I); Sacripanti himself, in describing his way of drawing, states that "more than drawing in line and square, drawing in space. Only a small piece of the architecture, then, should be drawn" [Ciancarelli, Remiddi 1998, p. 196]. The Roman architect's statement is reflected in many of his projects, the first of which were for the pavilion in Osaka, the Science Museum in Rome and the Hermits' Museum in Padua. Sacripanti perceives in its entirety the program foreseen by the competition in which the societies 'inhabitants' of the skyscraper had to have maximum visibility outside, configuring themselves, at the same time, as autonomous entities, but amplifies the character of mutability through brise soleil and projecting volumes that create a particular play of light and shadow.

Nocturnal views of the sacrificial project (fig. 2) recall Le Corbusier's thought about Buenos Aires in which the Swiss master imagines the skyscrapers of the new city: he imagines them at night, brilliant and reflected in the waters of the bay and notes this vivid image on a small piece of paper (fig. 3).

Charged in 1938 by the Argentine government with a real master plan for the capital, that little piece of paper is transformed into the perfect and complex graphics of the plan, preserving unchanged that grandiose image, which he had a night ten years earlier.

Le Corbusier's project was never realized; however, his influence and ideas reinforced the inspiration for the construction of the Peugeot skyscraper.

Fig. I. M. Sacripanti, detail of an elevation of the Peugeot skyscraper

Fig. 2. M. Sacripanti, photo of the model of the Peugeot skyscraper.
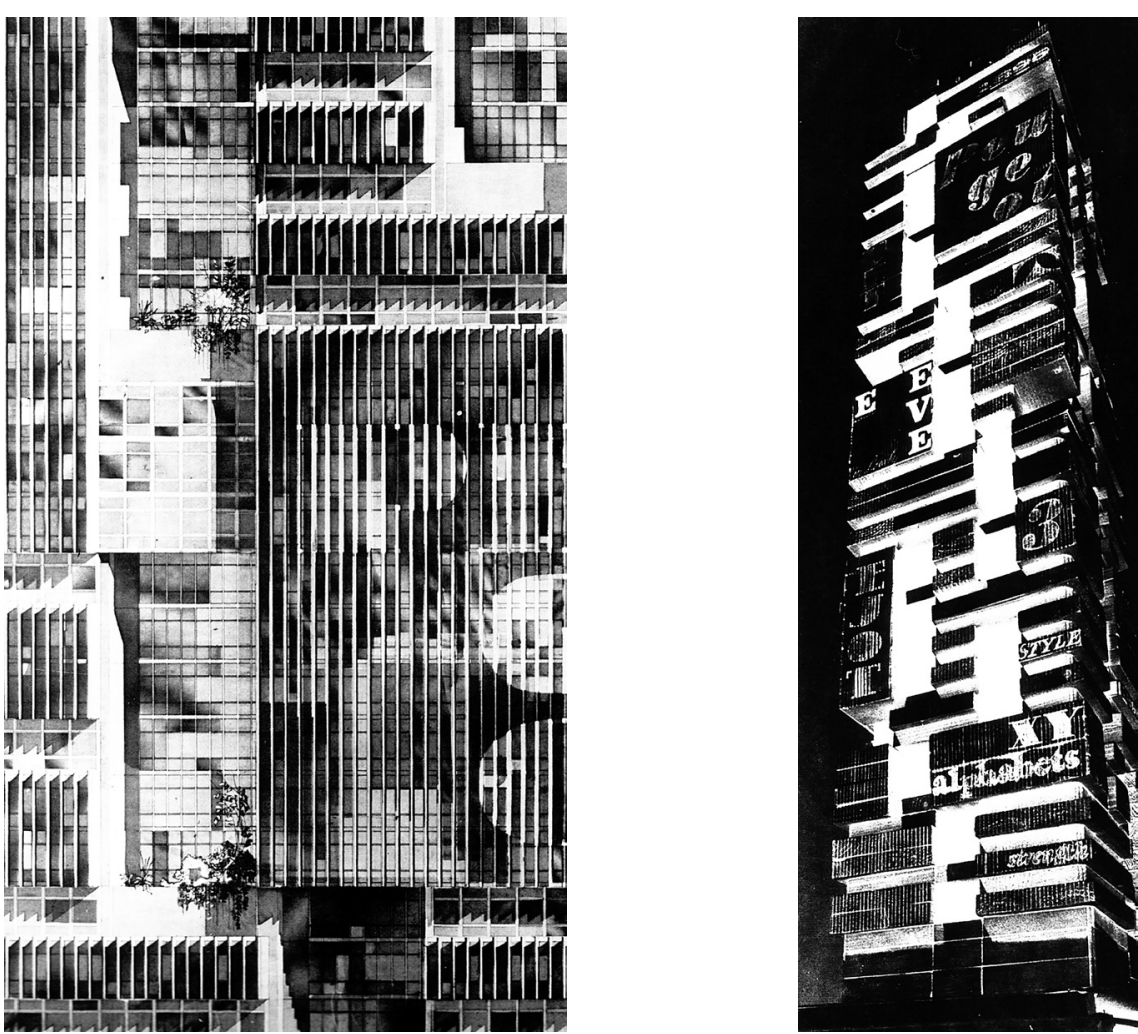


\section{The Peugeot International Competition}

This competition was one of the most important occasions for Buenos Aires, not only because it would have involved the construction of the tallest building in South America, but above all for the reactions, responses and debate that it generated.

The competition received as many as 228 project proposals from almost thirty countries. The Foreign Building Investment Company S.A., the joint-stock company set up by the car manufacturer Peugeot, the promoter of the competition, arranged a high financial compensation for the winners.

Peugeot was a reference point for the architecture of the time, because it proposed a significant theme at a time when skyscrapers were understood as the paradigmatic example of modern architecture.

The skyscraper was to be built in a nerve centre of the Argentine capital: it was designed near Plaza San Martín, a commercial artery terminal and prestigious area of large residences, located close to the infrastructure network with immediate access to the Retiro railway stations and the metro network; the proximity to the outlet of Avenida 9 de Julio, to be built in the future, would also guarantee a direct connection with the "urban heart" of the city (fig. 4).

The Foreign Building and Investment Company proposed the program: a building, intended for the Peugeot Company, covering about I 40,000 square meters, including a shopping and cultural center for a total investment of $\$ 20,000,000$. A skyscraper at least 60 floors high should have been proposed, which could have provided an incentive for participants to design an emerging architectural element. The intention of the investors would not only be to create a monumental building, but to propose a real example of contemporary architecture. The program of the Peugeot building was large and complex and required a group of offices, a set of accommodation, a commercial space with 40 rooms with an average surface area of 20 square metres to form a shopping gallery and another 10 rooms of 60 square metres for bank branches, spaces to host theatrical performances, ballets, concerts, conferences, national and international congresses, cinemas, etc., two amphitheaters with 500 and 250 seats, a reception hall, three restaurants, garage spaces for a total of 30,000 square metres, spaces for general services and also an infirmary and medical facilities.

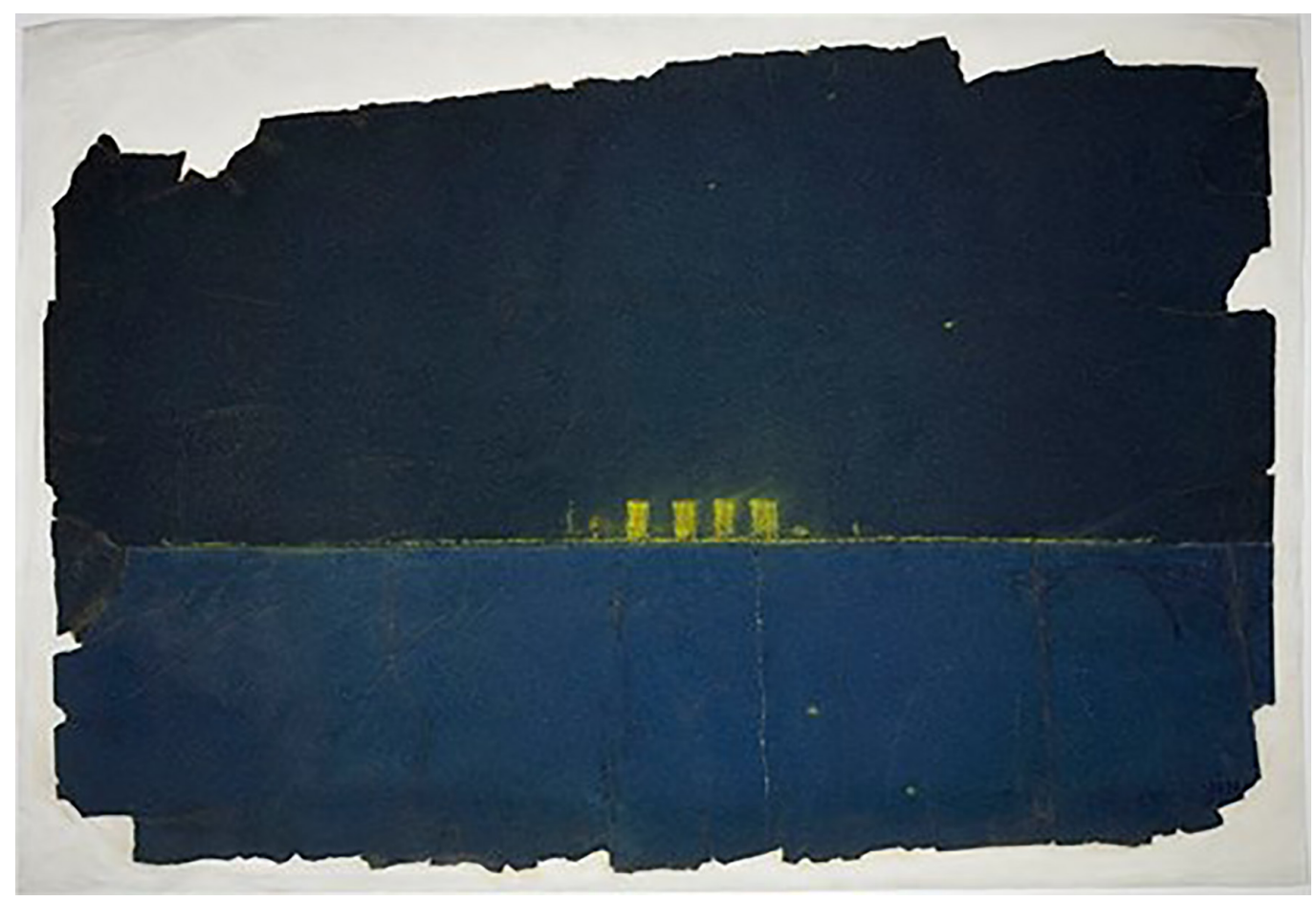


With regard to the size and height of the tower, the program referred to the Building Regulations for the city of Buenos Aires.

The jury formed by Martin Noel (President), Francisco Garcia Vàzquez, Francisco Rossi (Secretaries) and Eugenio Beadouin, Aberto Prebisch, Affonso Eduardo Reidy, Marcel Breuer and Federico Adolfo Ugarte, worked closely from 7 to 26 March 1962, the day on which the official results were issued.

The criteria for choosing the winning projects concerned the general approach and relationship with the urban landscape, architectural values, functional aspects, technical aspects, partial solutions and respect for the rules of the competition (fig. 5).

The first prize was awarded to the group composed of Brazilian architects Roberto Claudio Aflalo, Plinio Croce, Giancarlo Gasperini and Argentinean architect Eduardo Patricio, while Maurizio Sacripanti was given an honourable mention as follows: "This preliminary project is distinguished by the aesthetic research of the author, which is based on a skilful application of aluminium sheets, which seek to defend the interior from the action of the sun's rays, while at the same time obtaining an exceptional external treatment. These slats are proposed self-adjustable, through the action of an electronic photocell system.

The presentation of the facades is an exception and shows the sensitivity of the author and the possibility to express himself in a precious plastic language. It is necessary to underline that there is a total absence of harmony between the study of the plans, the structure and
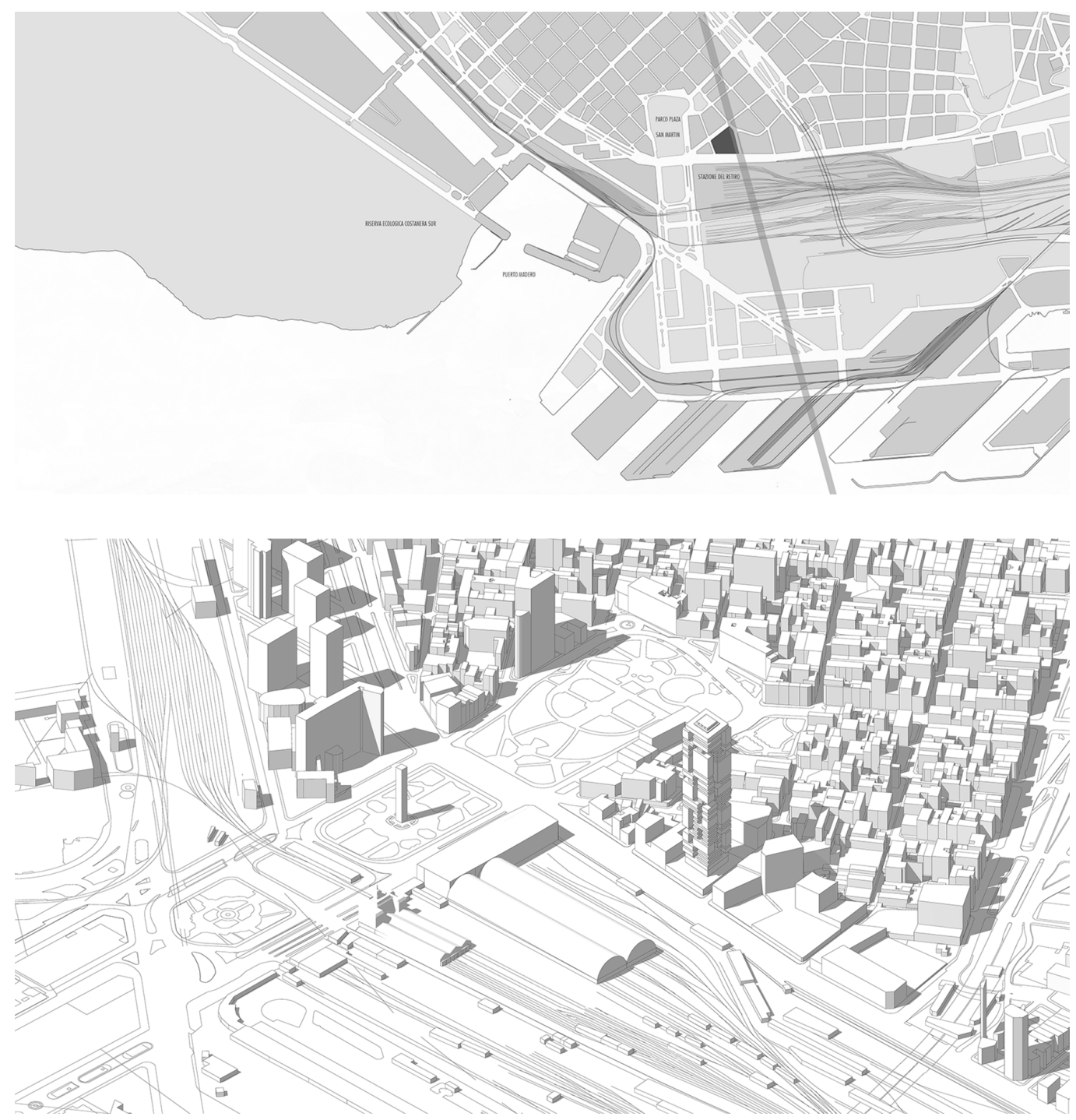
the functions with respect to the quality demonstrated in the treatment of the facades. It is considered critical to govern the entire composition on a non-orthogonal system (inclination corresponding to 75 to 55 degrees as indicated in the report) only to accompany both municipal lines. The wrong solution of the different functions produces an excess of usable surfaces, which is why this study exceeds the 40,000 square meters set by the notice" [I]. At Home, instead, Sacripanti's project was much appreciated.

Bruno Zevi, in L'architettura. Cronache e Storia wrote: "The jury, by assigning Sacripanti a simple honorable mention, has, in our opinion, missed the opportunity to properly report a very brilliant solution in everything, responding to the spirit of the competition. The comparison with the other award-winning projects imposes itself: not the winning one, nor the others appear superior to the one we are presenting either for coherence or fantasy" [Zevi 1963, p. 165].
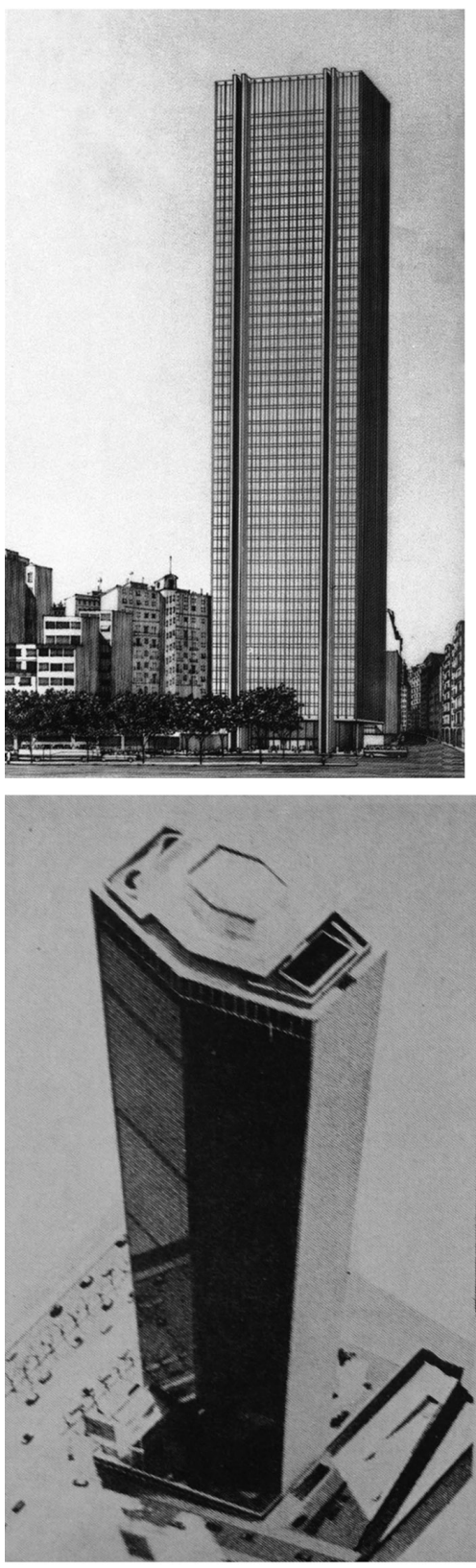
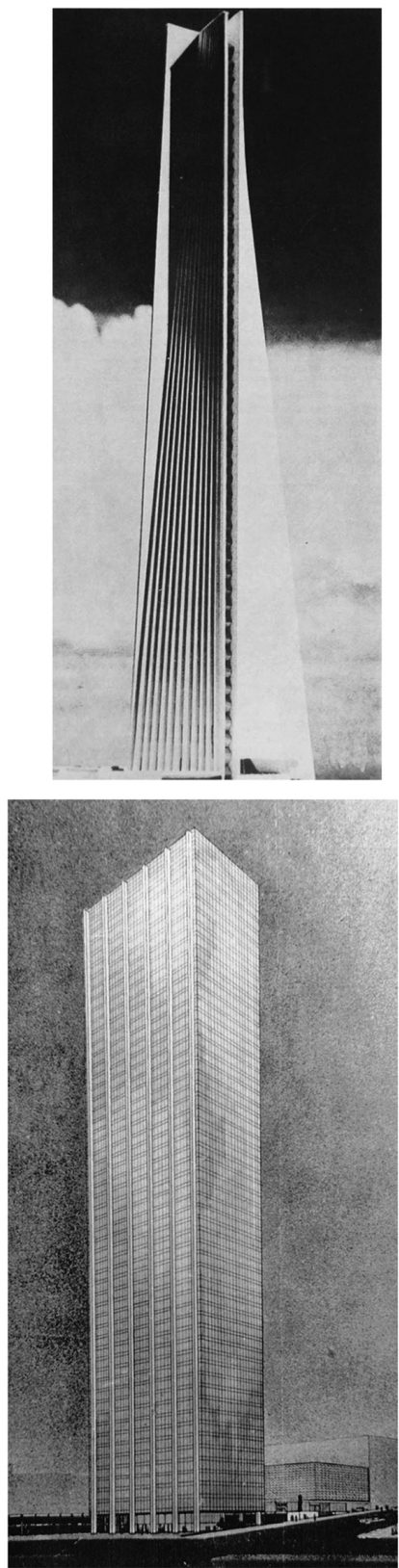
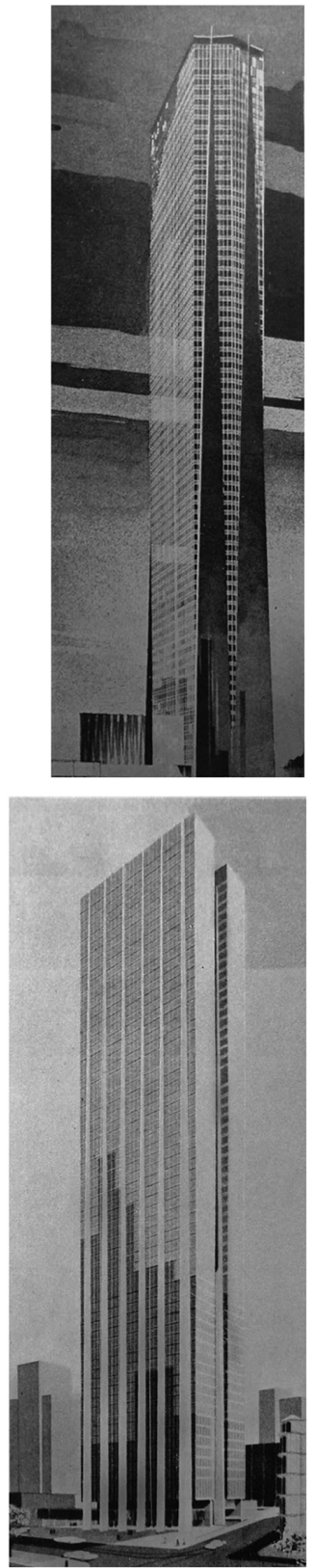


\section{Sacripanti's project}

The project proposed by Sacripanti, probably intended as provocative, was not understood in its real scope: it is a changeable building, which escapes from a fixed image, covered with laminae on which one can write and which, through their movement, can become a huge billboard (figs. 6, 7).

The term 'mutable' is an intense and profound concept that totally marries Sacripanti's poetics and finds its roots in philosophy, starting from Heraclitus' Panta Rei, that is, seeing the world as a continuous change.

The very definition of mutable leads us to a more complex meaning: we speak of mutability about something that changes often, that is inconstant and fickle: we often use it when we talk about time but also about mood. Changeability is therefore an existential condition of the human being; and Sacripanti understood it well, contemplating the nature of our world and its only lasting element, changeability, precisely.

The skyscraper was conceived with a strongly articulated structure, made up of overlapping, suspended, projecting blocks, opposed to the voids of the loggias and gardens that marked the composition of the facades; a new conception of the tower building obtained by decomposition of volumes and designed for the spatial and functional needs of each company that would settle (fig. 8).

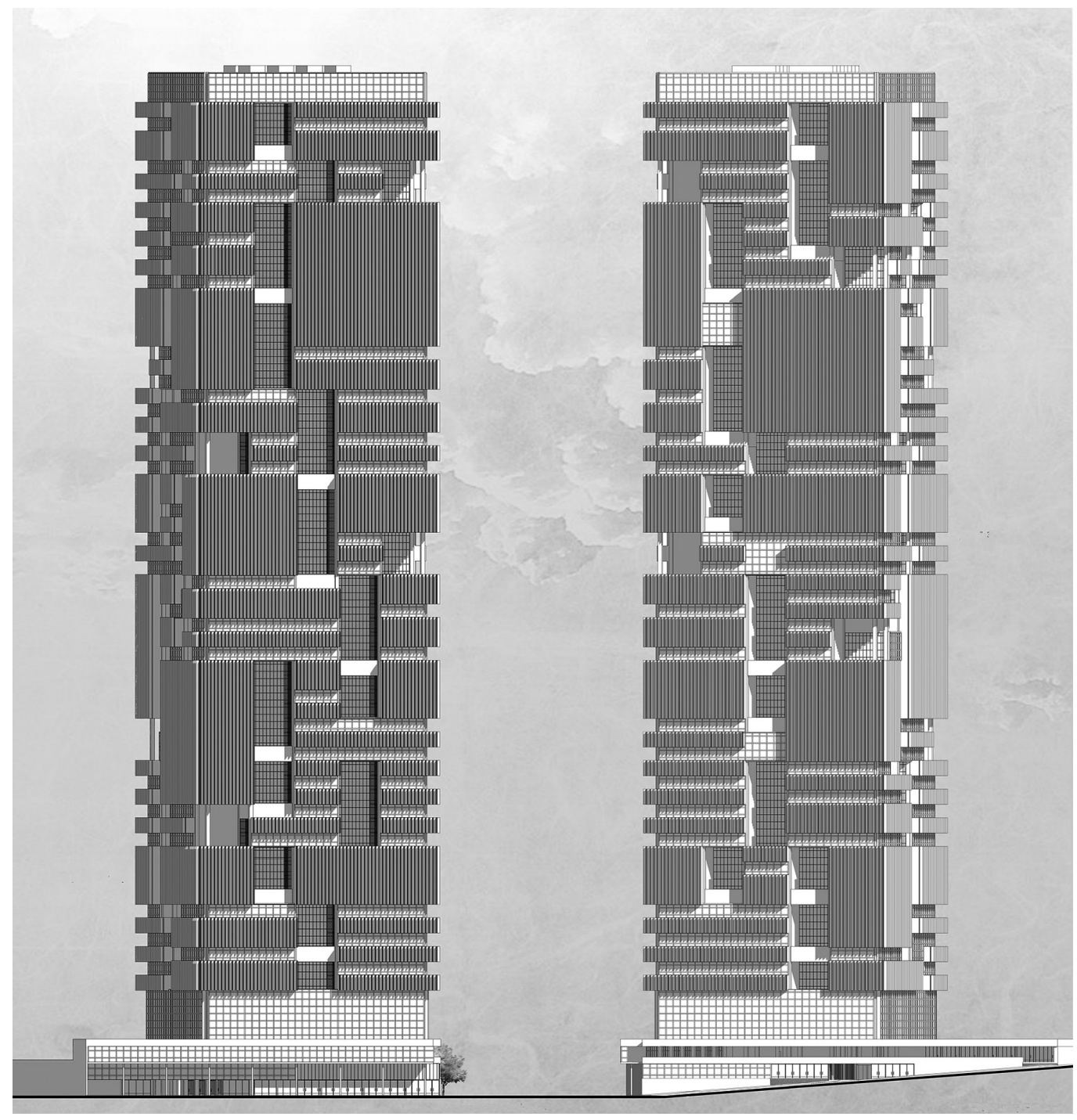


Fig. 7. Sacripanti's project, section (graphic elaboration by Chiara La Rosa).

Fig. 8. Sacripanti's project, axonometric exploded view (graphic elaboration by Chiara La Rosa).
These are the premises that led to the elaboration of the design idea: to achieve the maximum reading of the companies outside the skyscraper not only through advertising, but above all through the variable volumes that represented each company. On the one hand there was the desire to create an architectural artefact that could be partially modified over time to meet the needs of users and users, and on the other to use advertising as a compositional element.

In this project the passage from the aesthetics of 'things' to the generative process of 'things' themselves is fundamental; this concept, which then remained somehow present in Sacripanti's poetics, concerns not designing 'finished spaces', but alternatives within which different spatial solutions can be found (fig. 9). The trunk of the skyscraper, entirely modulated, follows a base mesh of $8.40 \mathrm{~m} \times 8.40 \mathrm{~m}$ for a total of $42 \times 42 \mathrm{~m}$, with angles of $75^{\circ}$ and $105^{\circ}$. The angles are defined by the inclination of the morphology of the block in which it was to rise, i.e. the angle created by the meeting between Avenida Libertador and Calle Esmeralda, and which becomes the main compositional element in the definition of the base mesh that controls, with all its own combinations, a building whose variability is very rich (fig. 10).
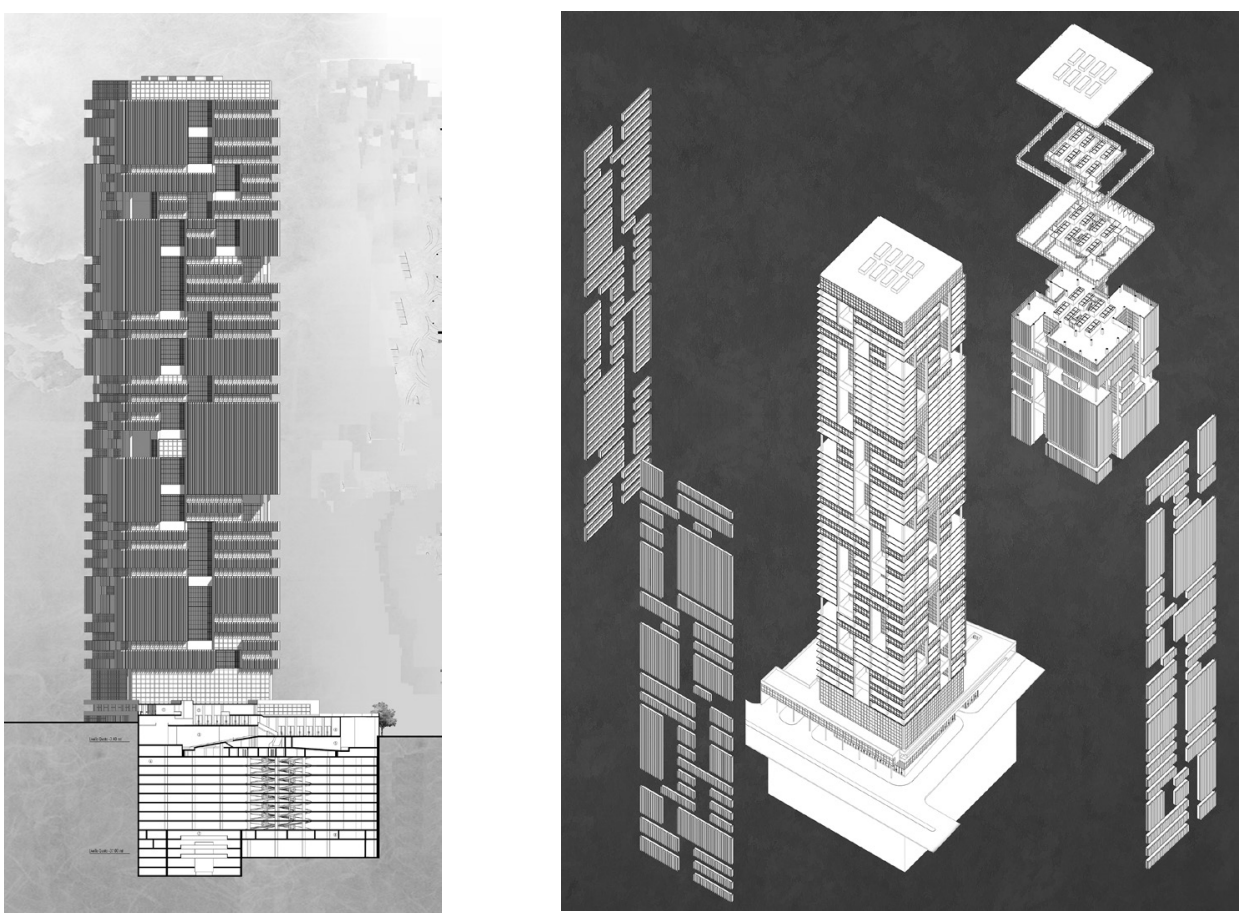

The plan develops on three concentric rings that represent three functionally and constructively autonomous surfaces: the internal surface contains the vertical connections, the intermediate surface the services, entrances, bathrooms and wardrobes, the external surface the office spaces (fig. II).

The forms proposed were designed with and without overhang. The former could either be welded onto the horizontal plane or added to the vertical one and on the outside they identified the volumes of the overhanging designed offices. The skyscraper was thus constituted as the sum of the volumes corresponding to the companies that would occupy it, marked by large cuts that would allow the view from outside of the heart of the skyscraper. On the skyscraper, to cover the overhanging surfaces and protect the sun, there were aluminum slats that could be self-directed through a system of electronic photocells. The slats would carry polychrome metal segments in their thickness and luminous channels that would form letters and figures to indicate the names of the companies. 
Fig. 9. Sacripanti's project, interior perspectives
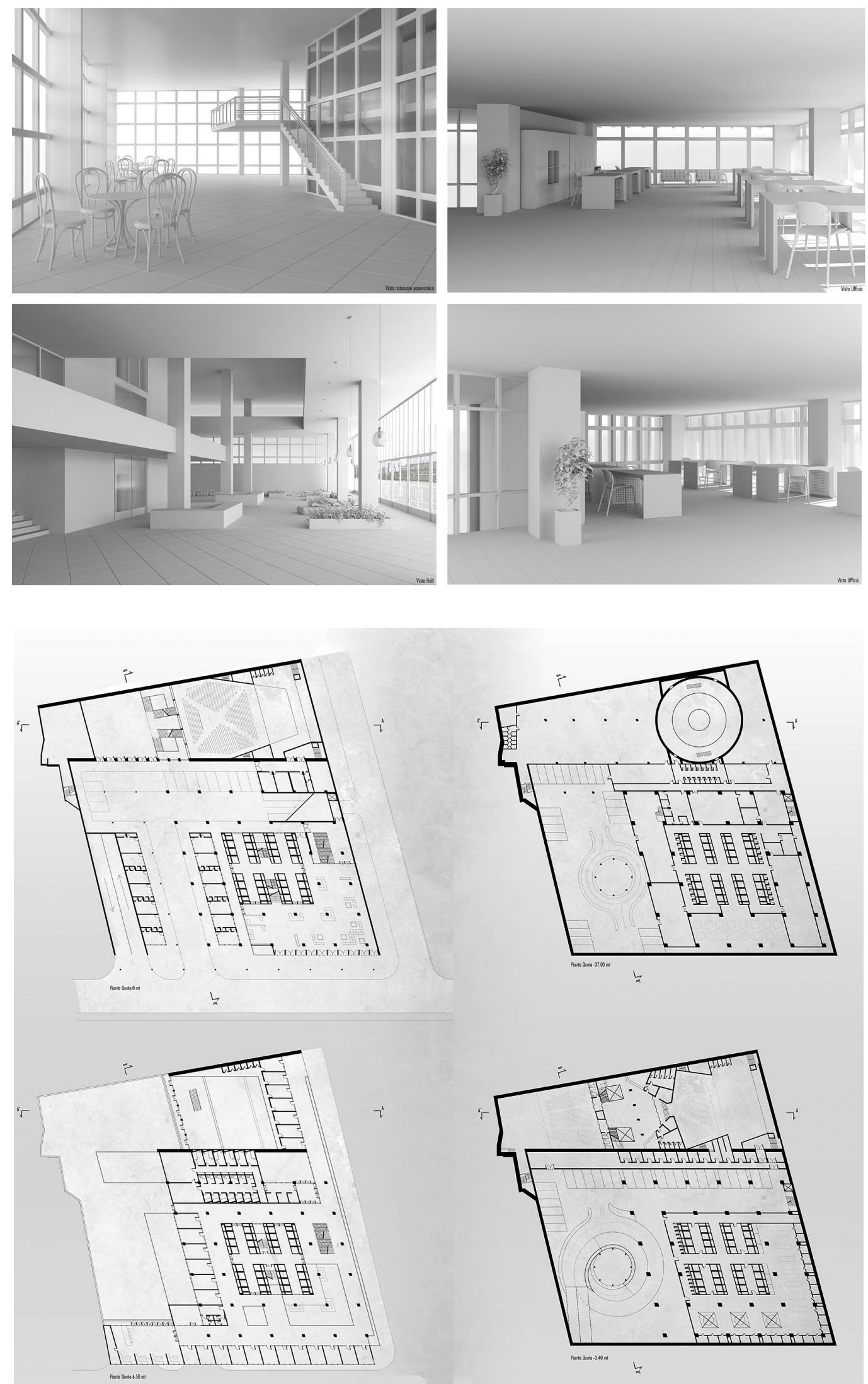
Sacripanti gave his skyscraper a definitive shape, even though he predicted that the facades would change over time according to the needs of the companies that would occupy the spaces (fig. 12).

The figurative exploitation of advertising is an intrinsic element, a form factor of the skyscraper; Sacripanti poses a challenge to it and decides to exploit it at the service of architecture in which the commercial and advertising element, consumer policy, insecurity and variability are tools at the service of design.

In this way, the individual activities that settle in the skyscraper are given the opportunity to be recognizable. Architecture then becomes a mirror of society, an object of consumption and for consumption, acquiring a conceptual value linked to contemporary artistic research.

The skyscraper therefore embodies an idea of the perennial variability of the building that reflects the changing nature of man and the activities he carries out and organizes. The mutable becomes an essential component: mobile, consumable, alterable tools are used by definition. The construction is entirely modulated, therefore possible of total prefabrication. Time enters the project for a world like ours, consumed over time.

For this reason, he identified in the drawing, not so much a substitute for the realization, but a parallel environment in which his proposals live a condition of concreteness.

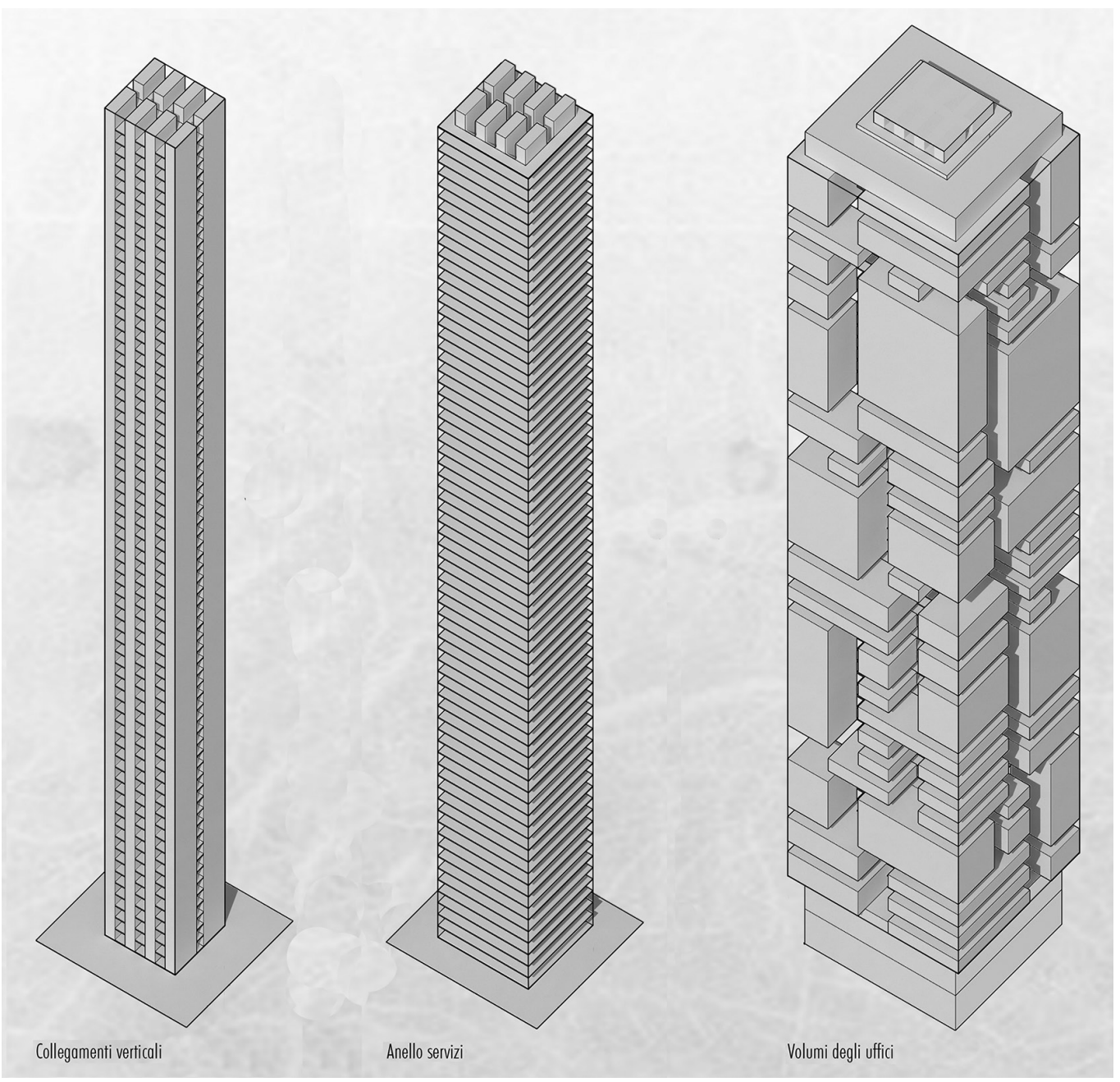




\section{Conclusions}

Graphic analysis and redrawing of unbuilt architectures are not autonomous actions because if you assume "the centrality of the project as a specific form of architectural knowledge, the representation constitutes a privileged place of its formation and elaboration, as of interpretation and critical analysis of the built work" (Ugo 2004, p 7). If you consider the drawing as one of the forms of knowledge, you can easily overcome the difference between built and unbuilt work. This is because the project, according to the intentions of its author, is always constructible even when, at the limit, it investigates the fields of utopia, because building is thinking [Heidegger Martin, 1952].

Texts and new and unpublished representations can tell about architecture along the sites of fruitful interaction between theoretical production and digital processing. In this sense, digital drawing, for its extraordinary elasticity, is very useful for graphic analysis of those projects of architectures in the drawer that, with pure expression of a pristine idea, have a greater expressiveness of the built projects.

"The digital models of architecture appeared to date have made a change we could define something like 'typographic revolution' introduced when Sebastiano Serlio and Palladio thought to communicate architecture through printed pages of a book. The crucial aspect of this revolution does not consist on the construction of three-dimensional illusions, more effective than in the past, but in the transformation of the three-dimensional representation of a building from image to a cognitive system, that is to say a database of well-defined spatial, dimensional and relational information. The reading of a work [...] introduces the need for new notations: not only an experimental verification of important spatial connotations, or elements such as the quality and the quantity of light, but also the perceptual verification of space as it will be built" [Gaiani 20I I, p. I2] [2].
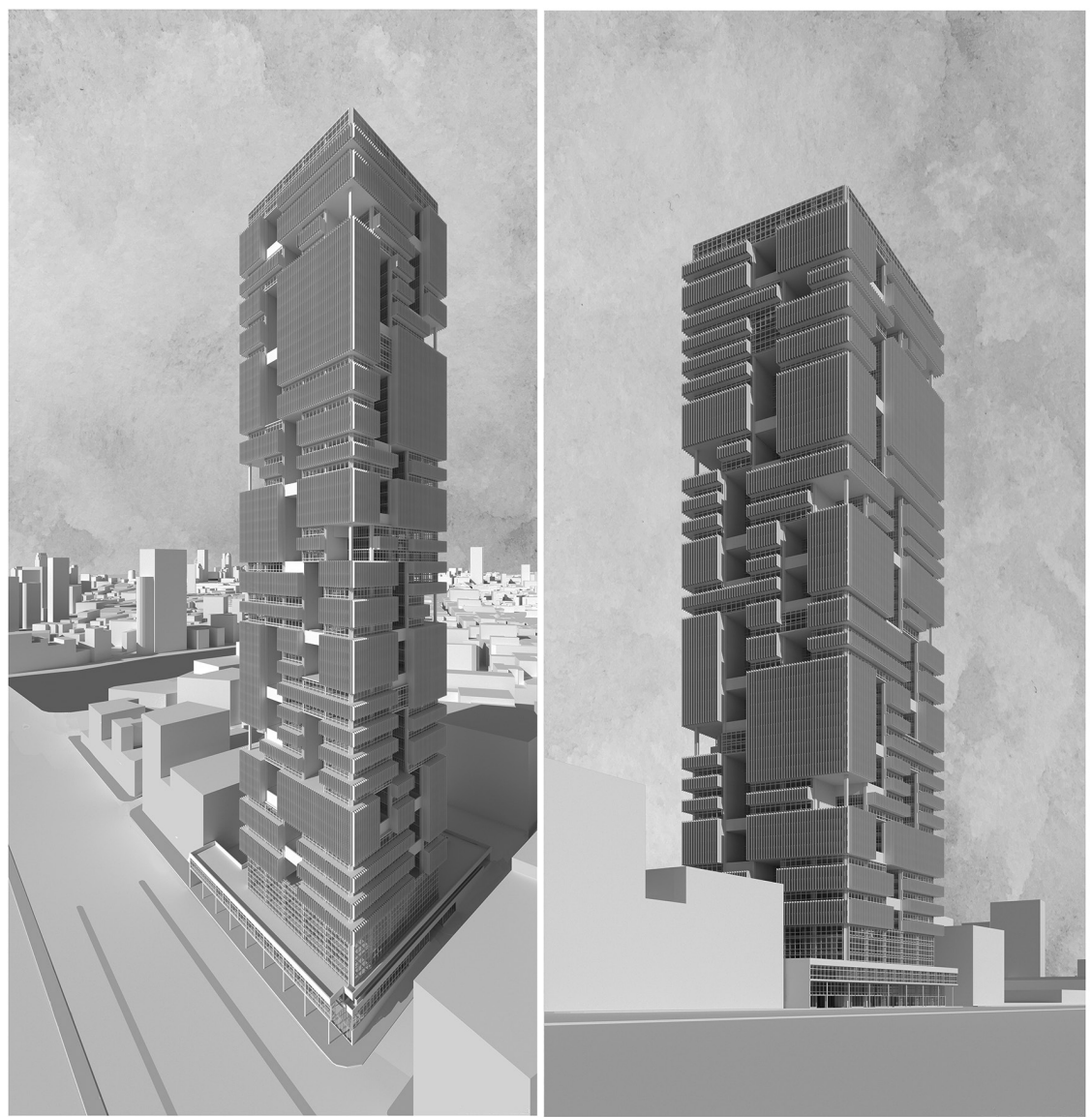


\section{Notes}

[1] Concurso del Edificio Peugeot, 1962, p. 33.

[2]While sharing the positions expressed in the article, result of common elaborations, the paragraph The Peugeot International Competition is to be attributed to Francesco Maggio with Introduction and Conclusions, while the paragraph Sacripanti's project is to be attributed to Chiara La Rosa.

\section{References}

Albisinni Piero, De Carlo Laura (a cura di). (20I I). Architettura/Disegno /Modello, verso un archivio digitale dell'Opera di Maestri del XX secolo. Roma: Gangemi Editore.

Ciancarelli Luca, Remiddi Gaia (1998). Più di questo non so dirvi... Intervista a Maurizio Sacripanti. In Neri Maria Luisa, Thermes Laura (a cura di). Maurizio Sacripanti maestro di architettura, 1916-1996. Roma: Gangemi, pp. 1 1 I-200

Concurso del Edificio Peugeot, Esmeralda y Libertador.Trabajos premiados. In Nuestra Arquitectura, 39I, 1962, Buenos Aires. p. 33 .

Gaiani Marco (201 I). Presentazione. In Maggio Francesco. Eileen Gray. Interpretazioni grafiche. Milano: Franco Angeli

Garimberti Marta, Susani Giuseppe (1967). Sacripanti. Architettura. Venezia: Cluva.

Giancotti Alfonso (2000). Maurizio Sacripanti: altrove. Torino:Testo\&Immagine.

Heidegger Martin (1952). Costruire abitare pensare. In Vattimo Gianni (a cura di) (2014). Saggi e discorsi. Milano: Mursia.

Neri Maria Luisa, Thermes Laura (a cura di). (1998). Maurizio Sacripanti maestro di architettura, 1916-1996. Roma: Gangemi Editore.

Sacripanti Maurizio (1973). Città di frontiera = Frontier City. Roma: Bulzoni Editore.

Ugo Vittorio (1994). Fondamenti della rappresentazione architettonica. Bologna: Ed. Esculapio.

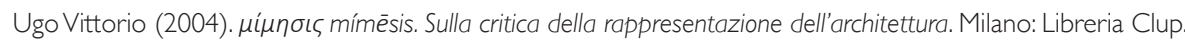

Zevi Bruno (1963). II grattacielo Peugeot. In L'Architettura. Cronache e Storia, anno VIII, 87, p. 1654.

\section{Authors}

Francesco Maggio, Università di Palermo, francesco.maggio@unipa.it

Chiara La Rosa, Università di Palermo, larosachiaa@gmail.com

To cite this chapter. Maggio Francesco, La Rosa Chiara (2020). Drawing the changeable. The competition for the Peugeot skyscraper by Maurizio Sacripanti. In Arena A., Arena M., Brandolino R.G., Colistra D., Ginex G., Mediati D., Nucifora S., Raffa P. (a cura di). Connettere. Un disegno per annodare e tessere. Atti del $42^{\circ}$ Convegno Internazionale dei Docenti delle Discipline della Rappresentazione/ Connecting. Drawing for weaving relationships. Proceedings of the 42th International Conference of Representation Disciplines Teachers. Milano: FrancoAngeli, pp. 2383-2404. 